\title{
Dal faro per il mare al pozzo per il cielo: la chiesa di Santa Croce a Bergamo nella memoria di Santa Maria della Grotta a Messina
}

\author{
Alessio Cardaci \\ Sereno Innocenti
}

\section{Abstract}

Le ricerche sulla cappella di Santa Croce a Bergamo e di Santa Maria della Grotta a Messina offrono, in questo saggio, l'occasione per ricordare e omaggiare il professor Mario Manganaro, un disegnatore generoso che ha profondamente influenzato la vita dei due scriventi. Una strana connessione del destino che lega le due città e gli autori al grande maestro. Tessere di un mosaico che si intrecciano e si annodano nel disegno di due importanti architetture, comprese e documentate attraverso lo sguardo del disegnatore 'dal vero' e del 'rilevatore contemporaneo' che integra l'analisi grafica tradizionale alla potenzialità offerta dai sistemi 3D laser scanning e image based reconstruction.

Parole chiave

disegno, rilievo, analisi grafica, ricostruzione virtuale, architettura medievale, Luigi Angelini.
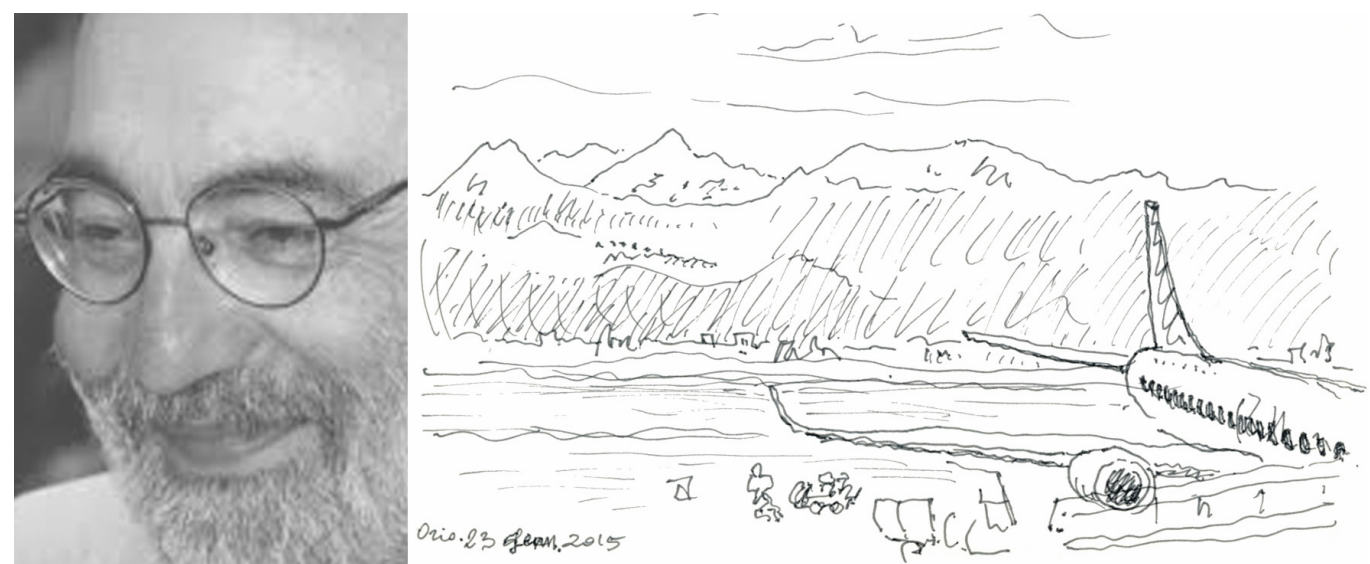


\section{Prologo}

Si narra qui di un viaggio, di un percorso durato oltre vent'anni. Una lunga strada intrapresa nel segno del disegno per ricordare un grande maestro, che legando Messina, la città dello Stretto, a Bergamo, l'antica fortezza della Serenissima, ha coinvolto i due autori influenzandone la vita e le sorti. La memoria, più che un saggio scientifico, vuol essere un omaggio per celebrare il professor Mario Manganaro, persona generosa ed incomparabile.

L'esperienza mia e di Sereno, attraverso due esempi condivisi nell'insegnamento di un esperto disegnatore, vuole testimoniare le peculiarità di una specifica scuola di pensiero che fonda il Rilievo sul contatto diretto con il costruito e non solo sull'osservazione indiretta dell'occhio elettronico di un sensore. Una riflessione sull'evoluzione della disciplina in un excursus temporale nel passaggio tra il vecchio e il nuovo millennio.

Fig. I. Disegni al tratto della costa messinese: a) vista verso Capo Peloro:

b) vista dello Stretto d Messina in prossimità della chiesa Santa Maria della Grotta (disegni di Mario Manganaro e Sereno Innocenti).
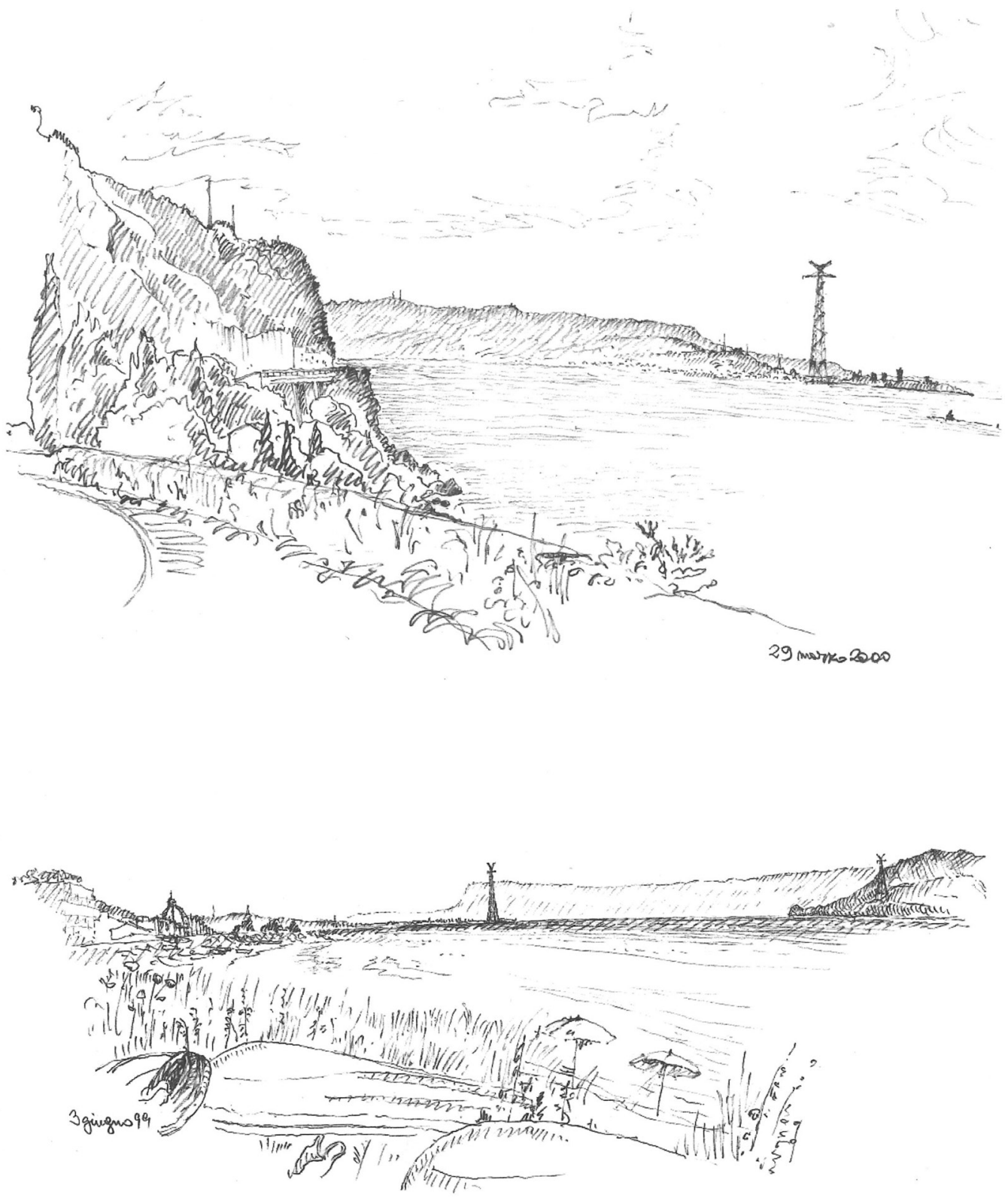


\section{Un faro per il mare e un pozzo per il cielo}

Durante la mia nomina presso la facoltà di ingegneria di Messina, sono stato titolare del corso di rappresentazione del paesaggio e intrapresi nell'ambito della ricerca uno studio sulla costa della città siciliana, compresa dal porto al Capo Peloro; l'ultima propaggine, il punto di confine dell'isola, I'llimite [Aricò 1999]. Sin dai primi sopralluoghi fatti individualmente con un motociclo o sull'auto assieme al professor Mario Manganaro, percorrendo la splendida costa messinese, mi resi conto come qualche cosa di particolarmente catartico, non solo mutava la scena, ma in qualche modo condizionava percezione, percorso e atmosfera (figg. la, lb). In località Grotte, infatti, la chiesa di Santa Maria, trasforma la sua pianta circolare in una sorta di giunto cardanico, un ideale meccanismo sul territorio atto a sottolineare e raccordare il percorso della costa, dalla sua genesi morfologica, concretizzabile nell'area portuale, fino al Capo Peloro. Giunti in prossimità dell'edificio, si ha la sensazione di essere di fronte ad un faro. II manufatto architettonico segnala con la sua presenza un evento di mutazione del territorio, mentre la sua destinazione d'uso lo trasforma in un faro per la fede; visibile anche e soprattutto dal mare, in quel particolare contesto, la chiesa-faro, trova il suo genius loci. Diverse e controverse sono state le attribuzioni progettuali e le datazioni della chiesa, non passata inosservata nei secoli ai suoi variegati disegnatori. Filippo Juvarra già intui l'importanza del ruolo, al punto di illustrarne magistralmente nella china dell'inchiostro la vestigia in una Veduta di Messina e piano urbanistico con il nuovo Palazzo Reale (Biblioteca Nazionale,Torino) e Willem Schellinks, nel I664, illustra anch'esso con due diversi punti divista il litorale dove Santa Maria delle Grotte degrada il suo arioso scalone d'accesso, nel tempo scomparso sino sulla battigia [Aikema 1983]; in una veduta dalla chiesa verso la falce e l'altra verso Capo Peloro (Osterreichische Nationalbibliothek, Vienna). Resta invece inconfutabile come a partire dal secolo XVI, esistesse nello stesso sito piccolo cenobio intitolato alla Vergine Maria detta la grotta (figg. I c, I d), oggetto di ricostruzione sulle rovine del tempio pagano di Diana; l'area pertanto già nel medioevo era stata sacralizzata dai cristiani per il culto alla Madonna (fig. 2). Dopo il triennio di conferma, fui chiamato per trasferimento presso la facoltà di ingegneria a Bergamo, con cattedra ad un corso al primo anno di Disegno. Ė mia abitudine, ormai consolidata nel tempo di lavorare con gli studenti su piccoli temi, disegnare architetture di dimensioni contenibili, facilmente accessibili per essere rilevate con semplici strumenti metrici ed essere restituite manualmente da un disegno geometrico di base. La chiesetta di Santa Croce, di cui erano in atto gli scavi di restauro, sembrava eletta alla bisogna. Portai dunque con

Fig. Ic. Disegno al tratto della costa messinese: 'coltellazione' grafica di un tratto di costa in prossimità di Grotte (disegni di Mario Manganaro e Sereno Innocenti)

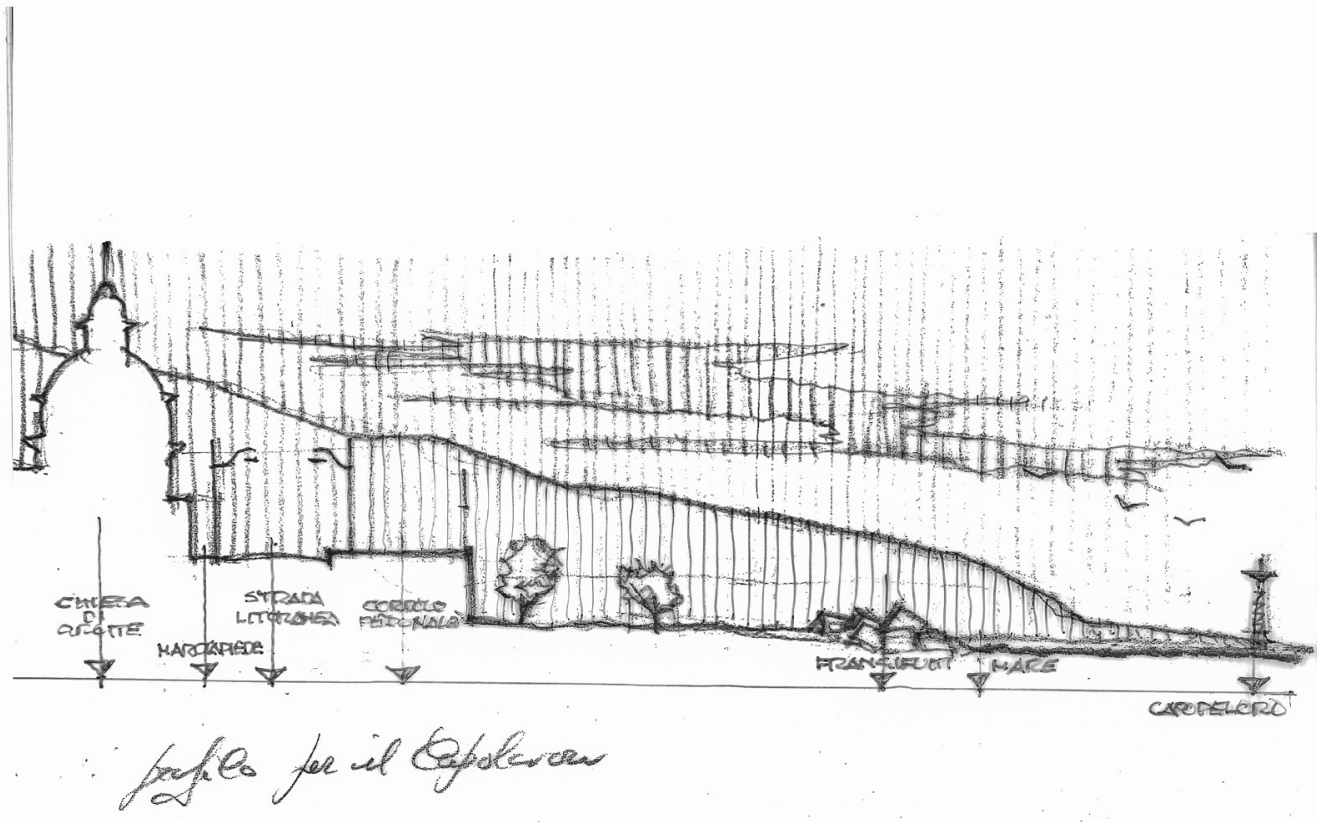


me l'esperienza messinese fatta con il professor Mario Manganaro, pertanto con gli studenti intraprendemmo un viaggio seppur breve al centro storico della città alla chiesa. Cercammo di registrare ogni cosa, sensazione ed emozioni. Lavorammo per metafore, simboli e persino per veri e propri ossimori architettonici, prima di prelevare qualsiasi misura, prima di stendere il metro a fettuccia o montare le canne metriche (in vera canna di bamboo), che oggi come allora si dovrebbe adoperarsi per il primo approccio con l'architettura e soprattutto, quando questa deve essere finalizzata ad una sua rappresentazione di base per la conoscenza, come sosteneva Giovanni Michelucci "per toccare con mano le pietre dei muri" II rilievo non escludeva quali fossero i percorsi di accesso al sito, con le relative pavimentazioni e strutture (figg. 3a, 3b). Ma era negli appunti di questo breve viaggio verso la curia, che della chiesa venivano registrate sul blocco degli appunti le sensazioni. Il cantiere in corso, con le sue infrastrutture di ponteggio la trasformava oniricamente in un altro Teatro del mondo e nella memoria del progetto di Aldo Rossi, si evinceva la metafora. Analoghe riflessioni portarono a paragonare nel suo contesto planimetrico la piccola chiesa ad una sorta di simbiosi compositiva simile a quella con cui Bernardo Rossellino seppe contestualizzare gli imperiosi edifici della piazza di Pienza, attorno allo storico arredo urbano rappresentato dal pozzo. In questo susseguirsi di queste riflessioni trasversali, arrivammo persino all'estremo paragone

Fig. Id. Disegno al tratto in prossimità della chiesa Santa Maria della Grotta (disegni di Mario Manganaro e Sereno Innocenti).

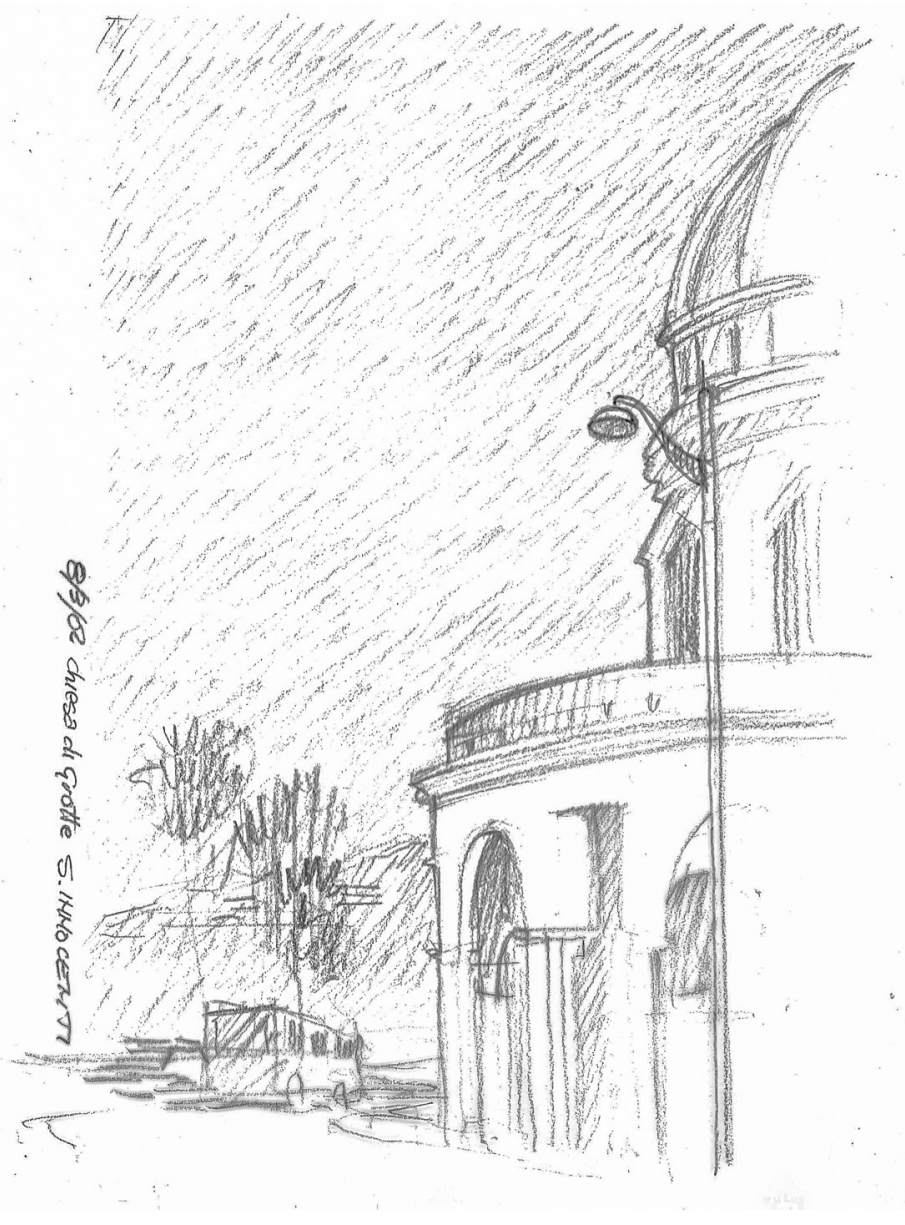

di comparare il coinvolgente volume circolare di Santa Croce nell'epilogo cinematografico di Akira Kurosawa poi successivamente ripreso dall'architetto Carlo Simi nelle scenografie della trilogia del dollaro per il regista Sergio Leone (fig. 4). Con la sua pianta centrale, Santa Croce ci riporta al culto del cerchio, al culto solare dei primitivi o nelle attuali religioni, nei miti o nei sogni, nei motivi mandala del Tibet, negli astrolabi delle prime concezioni astronomiche, ma è soprattutto simbolo di vita. La scrittura narra qualche cosa di simile anche a 
proposito di Budda, che al momento della nascita sormonta il fiore di loto per contemplare le dieci direzioni dello spazio. II fiore di loto ha in realtà otto raggi, ma completano la decina quello in direzione della terra e quello in direzione dello spazio. La pianta della chiesa è pertanto costituita da un impianto ottagonale, i cui assi radiali e compositivi, partono dall'area più baricentrica del cortile delimitato dal corpo di fabbrica dell'antico episcopio con l'aula della curia. Si può azzardare così anche per essa l'ipotetica lettura di dieci assi compositivi dello spazio: otto tracciabili dalle lobature e due dalle simmetriche direzioni del cielo e della terra.Terra e cielo sono così collegati nella fede cristiana e materializzati nella muratura della chiesa in conci di pietra irregolari con faccia vista a spacco di cava. Questa congiungente impalpabile è comunque percepibile raggiungendo il sito attraverso i suggestivi percorsi che dal centro storico (piazza Vecchia) di Bergamo portano attraverso il duomo, il palazzo della ragione e Santa Maria Maggiore a scoprire il cortile della curia vescovile. Subito è percepibile come gli edifici che circondano la piccola chiesa condizionano la sua convivenza all'interno del cortile e pur evincendo che l'edificio sia stato il battistero della città prima di diventare cappella vescovile, la sua vista zenitale o la semplice osservazione cartografica, può lasciar supporre che l'area occupata da Santa Croce potrebbe essere quella destinata ad un pozzo (della fede)... un pozzo per il cielo!!!

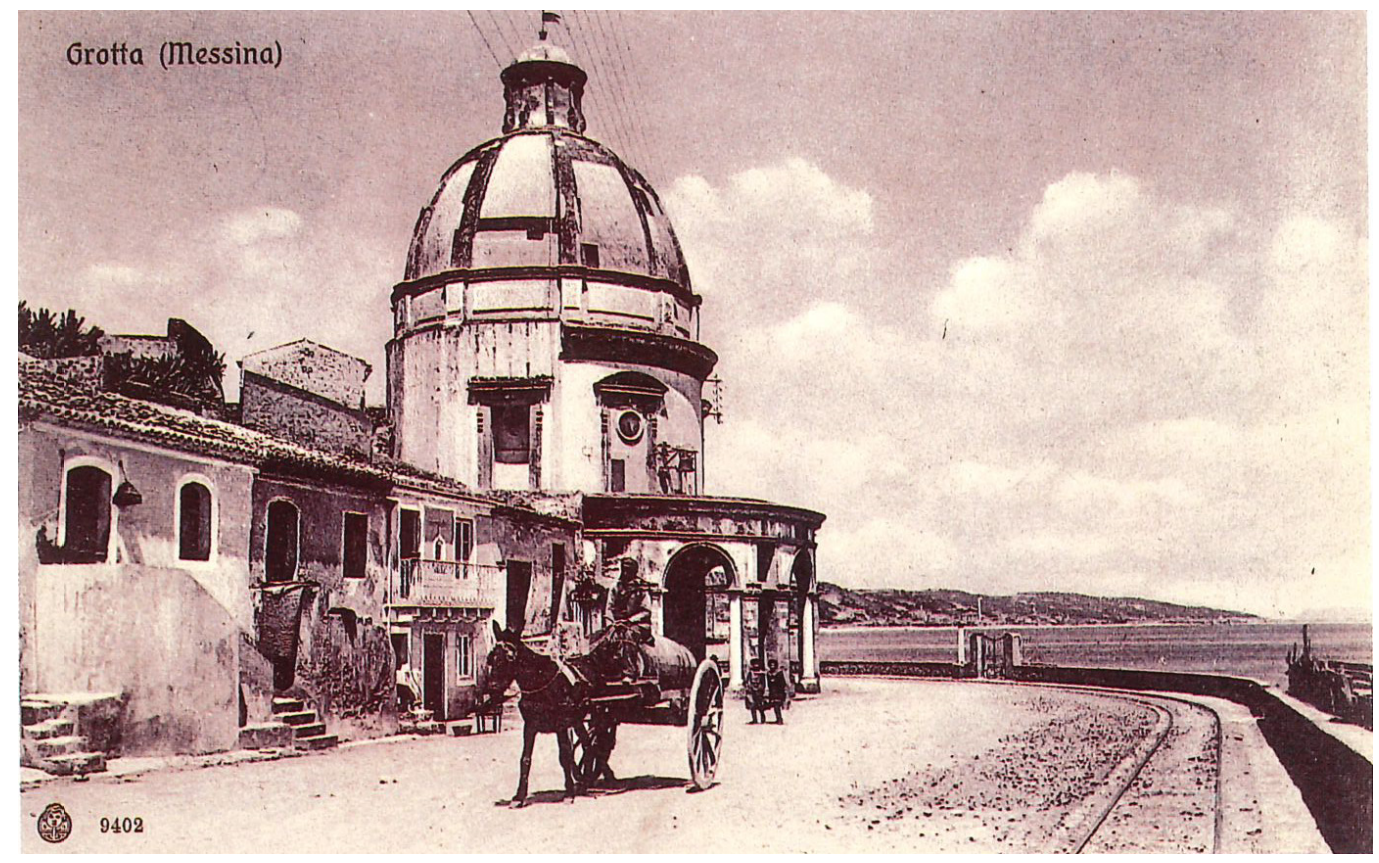

\section{Interludio}

Il professor Mario Manganaro mi ha avvicinato al Rilievo ed insegnato che esso è uno strumento di comprensione del passato, importante per vivere il presente e per proiettarsi verso il futuro; le architetture raccontano la loro storia, basta solo ascoltarle. II disegnatore attraverso l'osservazione diretta legge il segno del tempo e le sue metamorfosi sul costruito, quindi ne conserva e ne documenta la conoscenza attraverso il segno grafico. II professore era un uomo della tradizione che, pur conoscitore delle moderne tecniche di acquisizione indiretta con sensori, non le amava particolarmente. lo, allora giovane ricercatore affascinato dai nuovi strumenti e dai nascenti software di restituzione, non ho mai condiviso il suo punto di vista e, talvolta, sentendomi quasi ostacolato nelle mie aspirazioni di ricerca. Solamente negli anni ho compreso il suo insegnamento, appropriandomene ed evolvendolo attraverso l'integrazione dell'analisi grafica tradizionale alle potenzialità offerte dai sistemi 3D laser scanning e image based reconstruction. 


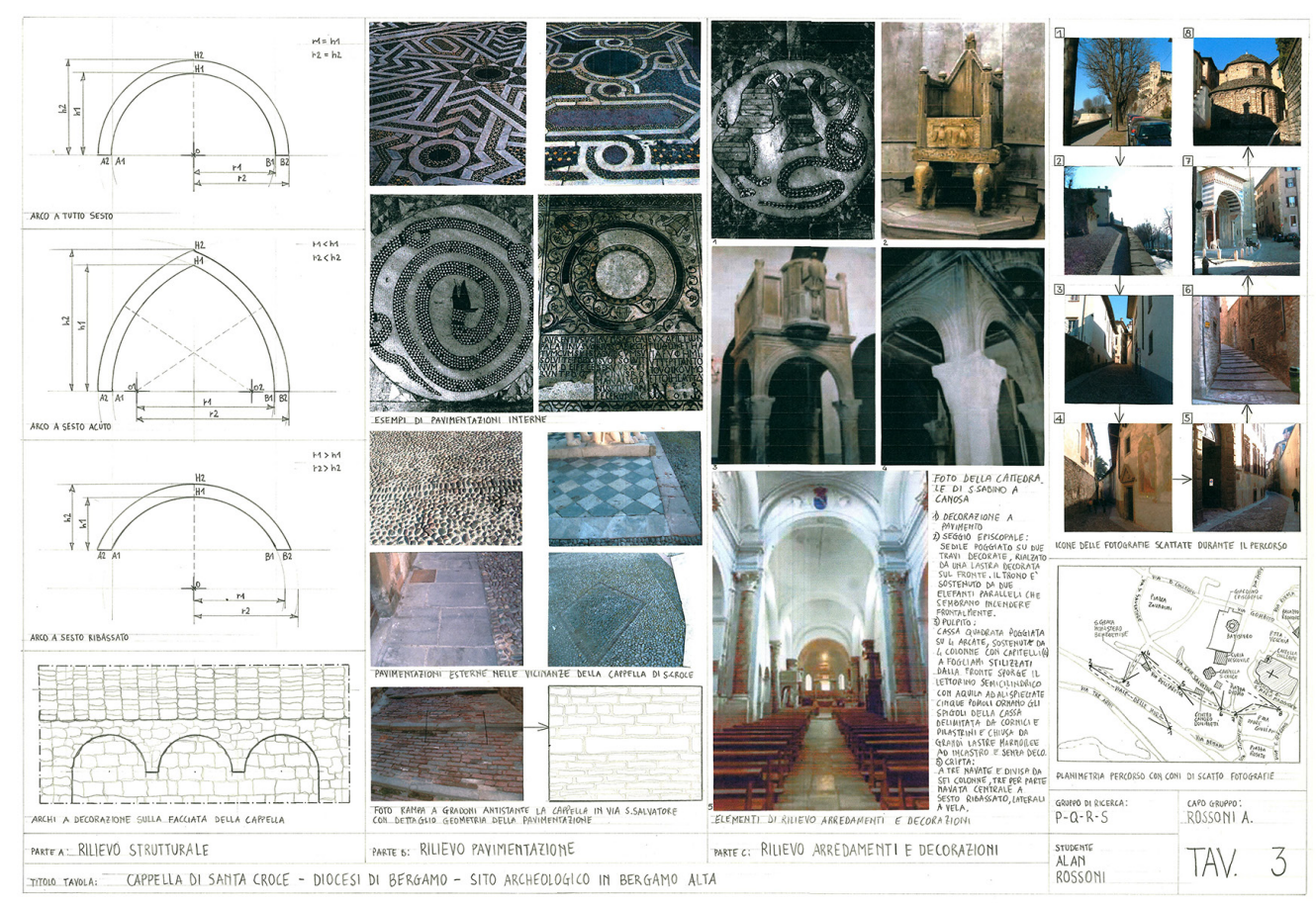

Fig. 3. Tavole sinottiche degli studenti di Piazza Vecchia e Santa Croce Bergamo:
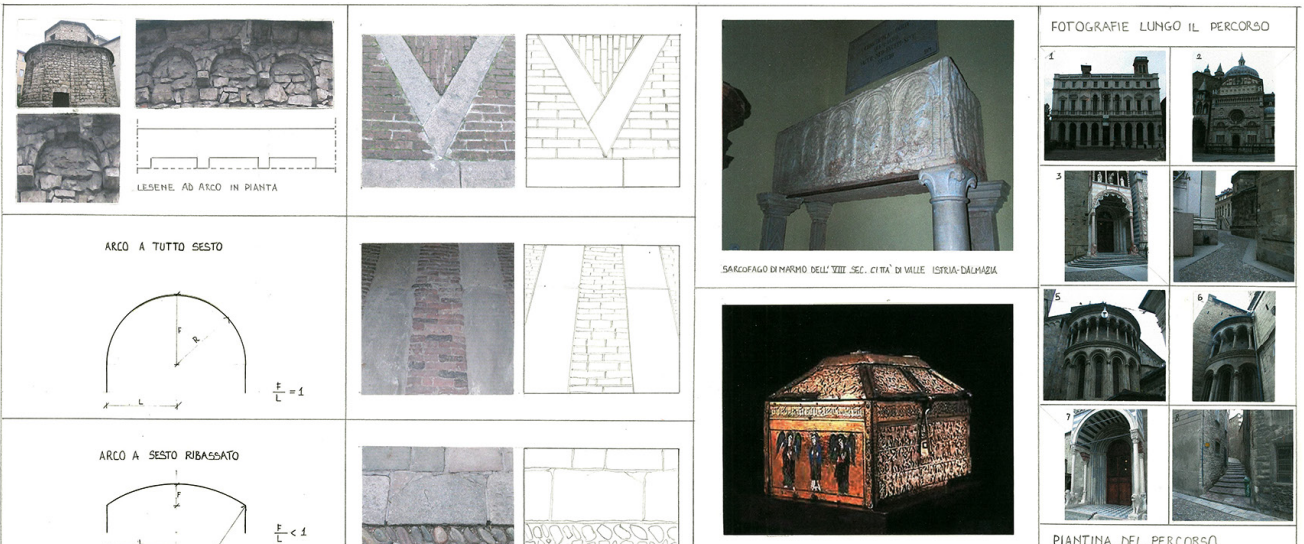

b) strutture.
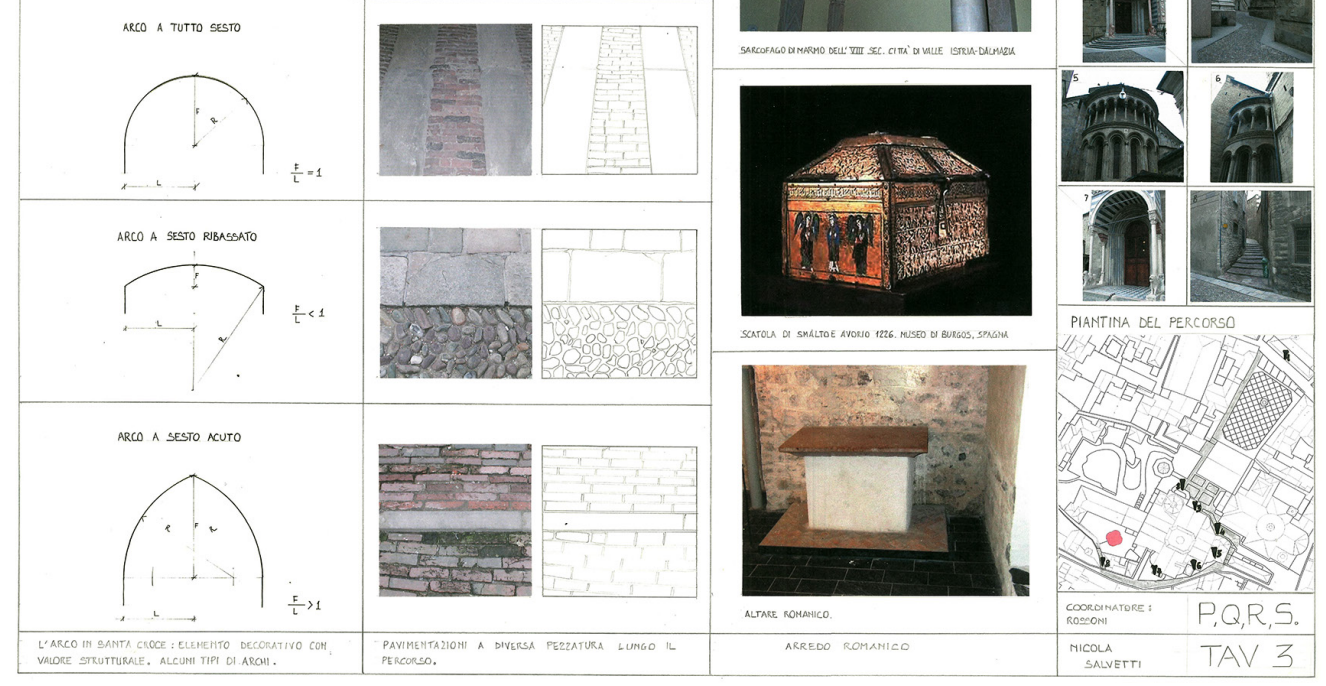


\section{II rilievo 3D della chiesa di Santa Croce tra conoscenza metrica e storica}

L'attività di ricerca che qui si riassume concerne la chiesa di Santa Croce in Bergamo; finalizzata all'intervento di restauro sull'opera, essa ha inteso fornire, attraverso il rilievo 3D, quell'apporto in termini di conoscenza storica, geometrica, costruttiva e stratigrafica, che appare sostanziale per le operazioni di conservazione, catalogazione e valorizzazione (fig. 5). La piccola cappella romanica si trova in un cortile tra la curia vescovile e la cattedrale di Santa Maria Maggiore; essa è caratterizzata da una particolare planimetria quadrilobata e si sviluppa su due livelli principali, privi di comunicazione interna perché divisi da un sistema voltato, e un tiburio [Fortunati, Vitali 2000]. II piano superiore è ritmato da sottili colonnine collegate da una serie di tre piccoli archi in laterizio e provvisto di due monofore strombate; quello inferiore è invece privo di lesene, ha una porta a livello del piano di calpestio medievale e due finestre rettangolari.

La cappella fu messa completamente in luce negli anni '30 del secolo scorso da Luigi Angelini nell'ambito del suo piano di risanamento per città alta [Angelini 1940; Angelini 1963]; infatti a causa dell'addossamento di edifici moderni di vario genere, essa risultava quasi nascosta e quindi, nella sua globale configurazione, sconosciuta; nel corso dei restauri il piano di calpestio del cortile fu probabilmente abbassato, i tetti furono completamente rifatti e furono rimossi tutti gli intonaci, dei quali rimane oggi solo qualche piccolo lacerto. I giunti

Fig. 4. Schemi del

restauro (allora in corso) impressioni metaforiche, oniriche e di confronto durante il disegno dal vero di Santa Croce all'interno del cantiere nell'ottobre del 2005 (disegni di Sereno Innocenti).
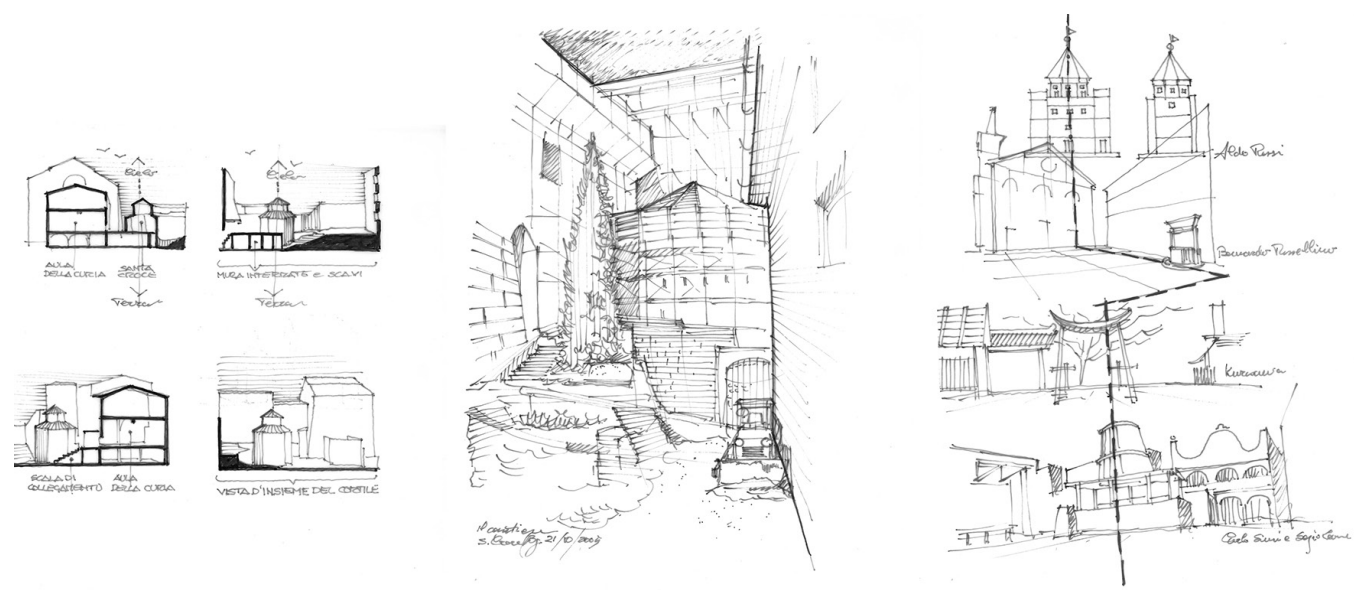

della muratura esterna furono completamente 'ripassati' in cemento e la muratura integrata con intenti mimetici che rendono ancor oggi difficile la lettura e l'interpretazione stratigrafica (fig. 6).

La particolare pianta quadrilobata, a parere di alcuni studiosi, trova i suoi confronti più pertinenti in edifici battesimali; questa somiglianza, unitamente alla presenza dell'acquedotto, ha indotto molti ad ipotizzarne una funzione battesimale, nonostante ne manchino i riscontri nella documentazione e - soprattutto - nell'assenza di tracce della vasca battesimale [Venanzio 1959; Ghiroldi 2007].

La chiesa di Santa Croce deriva da una composizione piuttosto complessa di volumi che hanno generato un edificio per nulla banale e probabilmente realizzata con molte difficoltà tecniche (ad esempio, l'inserimento della volta asimmetrica del piano terra, e la gestione del raccordo architettonico dai quattro lobi al tiburio sopra il secondo livello). È evidente un'idea iniziale di spazio riconducibile a una costruzione con più assi di simmetria, basata su un centro ('asse verticale dell'edificio) rispetto al quale sono tangenti le quattro circonferenze che disegnano la pianta quadrilobata, ma la fase costruttiva, pur seguendo grossolanamente questa impostazione, non l'ha rispettata in modo rigoroso: le circonferenze sono dei tondi a raggio e curvatura variabile, gli allineamenti appaiono casuali, non regolari segmenti rettilinei 
Fig. 5. La chiesa di Santa Croce nel contesto di città Alta.

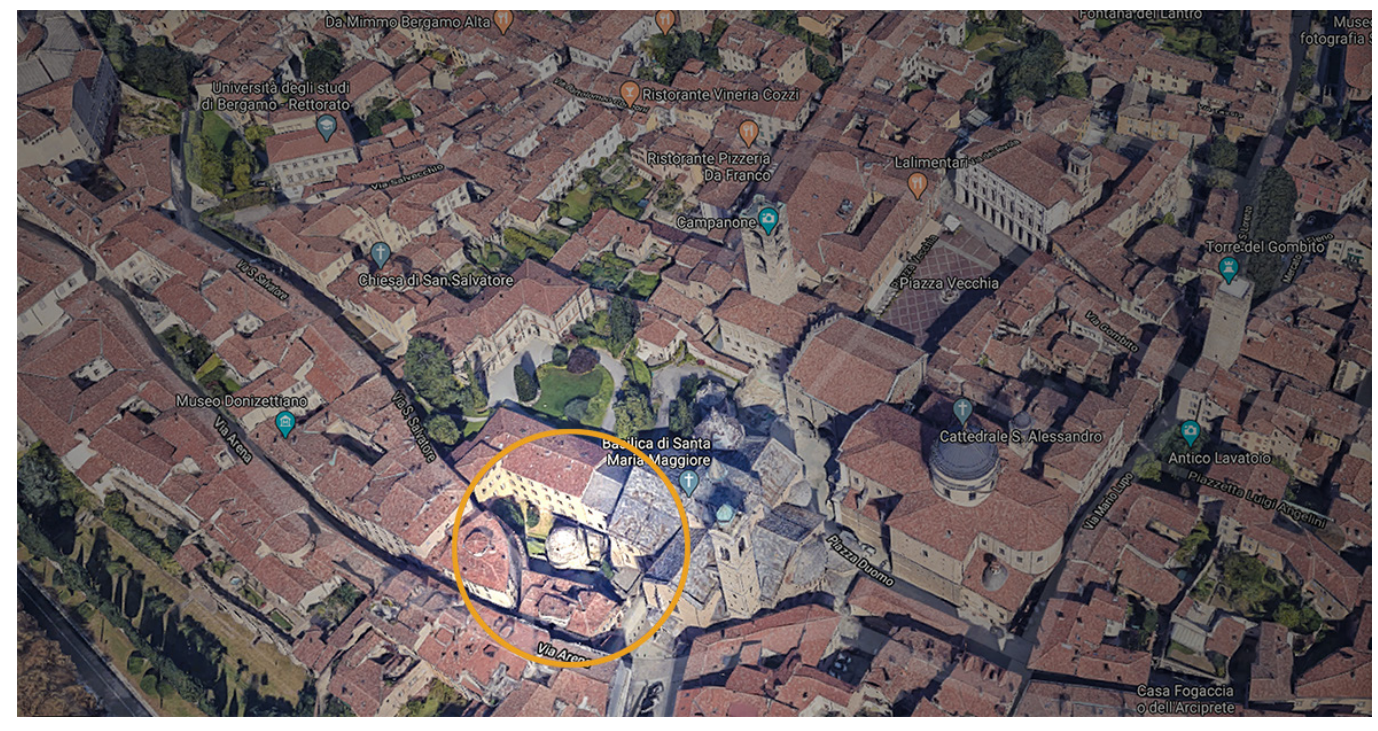

ma linee incerte e ondeggianti. Soprattutto, l'esistenza di più riseghe di fondazione differenti tra loro è testimonianza di aggiustamenti in corso d'opera, finalizzati alla correzione dei volumi della costruzione nelle sue prime fasi di realizzazione. Infine, la stessa idea unitaria di spazio che lega all'esterno la pianta e l'elevato in ragione di un rapporto di $2 / 3$, all'interno è contraddetta dalla volta del solaio che divide la chiesa in due ambienti [Cardaci 20।3; Cardaci et al. 2013].

Davanti a questo contrasto tra modello geometrico e realizzazione viene spontaneo chiedersi quale fosse il ruolo del capo mastro nel medioevo e quale a sua influenza sul cantiere. È proprio in ragione delle difformità esistenti tra il modello ideale e l'edificio realmente costruito, che si è deciso di operarne la lettura attraverso il rilievo automatico giacché il rilievo tradizionale, sia esso diretto sia strumentale, lascia al rilevatore una possibilità interpretativa della geometria, mediata dalla sua conoscenza e cultura, che sono inevitabilmente lontanissime dalla mentalità simbolica e analogica medievale. La scelta dei punti da misurare (ovvero, la selezione tra ciò che è da misurare e ciò che, invece, può essere trascurato) si manifesta sin dalle fasi iniziali del disegno degli eidotipi, schizzi indispensabili nel rilievo tradizionale per riportare le misure di volta in volta eseguite. Ancora, nella schematizzazione delle piante, delle sezioni e dei prospetti è già configurata un'idea della geometria regolarizzata e gerarchizzata tra le parti ritenute più importanti.
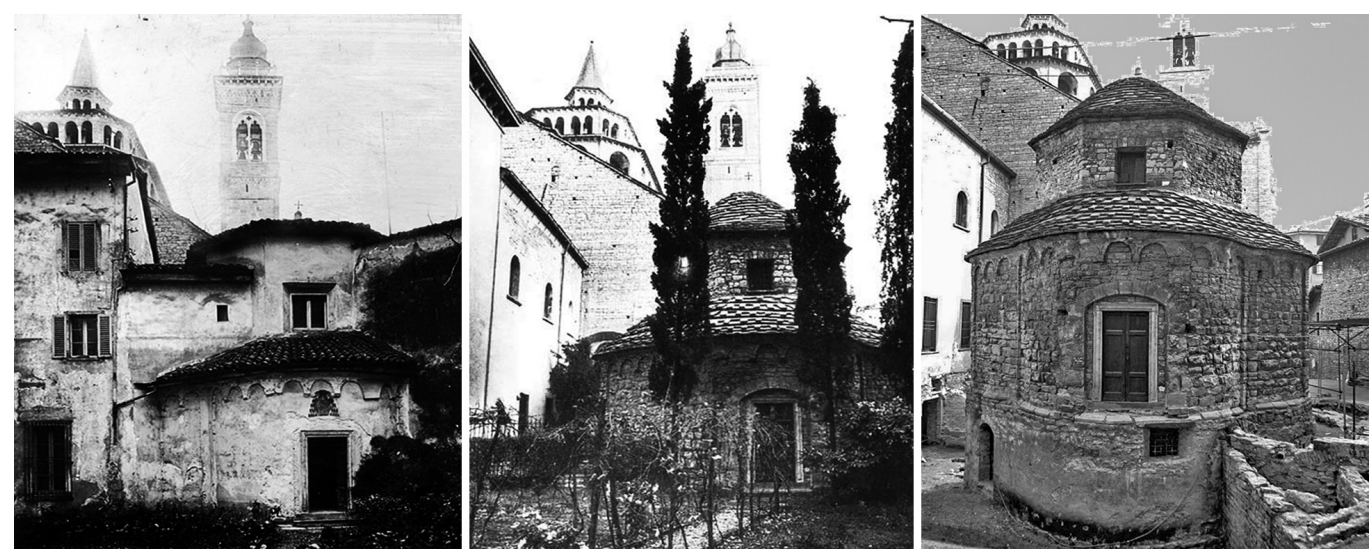
Inversamente, il rilievo automatico è caratterizzato da una sorta di incapacità dello strumento di misura di operare delle scelte 'intelligenti'. II laser a scansione rileva tutto ciò che è intorno a lui e a lui visibile, senza però realmente vedere ciò che misura e senza distinguere per importanza le parti dell'edificio. Ogni elemento è interpretato semplicemente come una sequenza di punti distanziati più o meno costantemente tra di loro. In definitiva, uno strumento di acquisizione automatica non possiede la capacità umana di interpretare forme e geometrie ed è atto a restituire, quindi, proiezioni ortografiche e/o cross-section, quali semplici sequenze di punti, non condizionate da una forse erronea e precedente interpretazione della spazialità del monumento. Una scansione è una rappresentazione 3D dell'oggetto: una fotografia solida che permette di ricavare un'immagine in cui ogni pixel fornisce anche la posizione spaziale di ogni particolare catturato dallo strumento.

Un rilievo più accurato dà ragione anche dell'irregolarità costruttiva dell'edificio, che non deve essere considerata il degrado di un'idea progettuale dovuto all'imprecisione dell'accidentale realtà del cantiere, ma una peculiarità degli edifici medievali (fig. 7). La geometrizzazione e rettificazione, che di consueto si applica nella rappresentazione grafica di strutture che di fatto sono prive o quasi di pareti rettilinee o di rigorose simmetrie, sono dawero fuorvianti per gli edifici romanici, la cui regolarità è apparente, in particolare per quelli del primo romanico, che si caratterizzano per esecuzioni e soluzioni tecniche ancora piuttosto
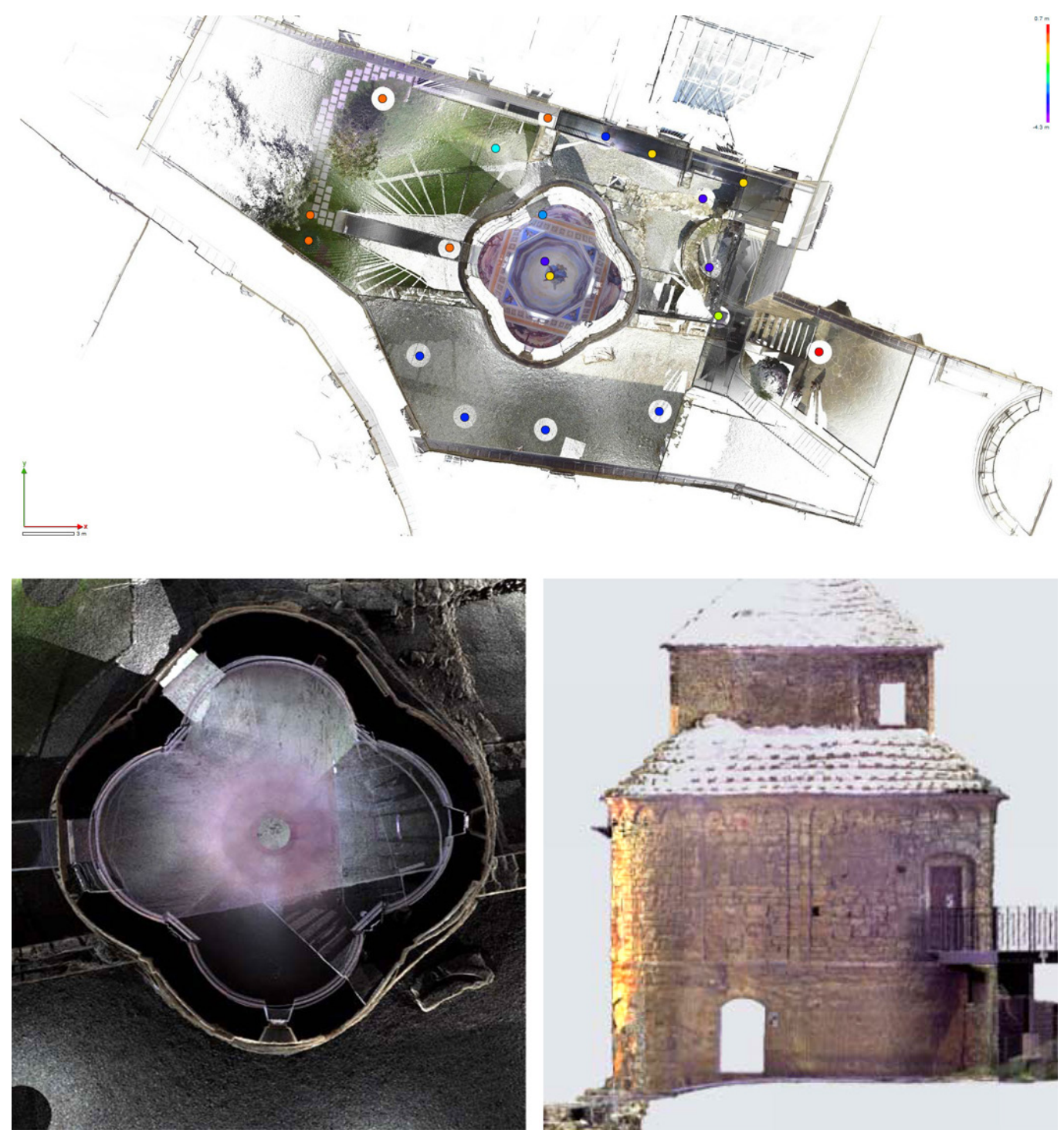
incerte. È di conseguenza chiaro che questi progressivi aggiustamenti del profilo degli alzati, se correttamente rilevati e rappresentati, sono elementi che concorrono alla datazione e alla comprensione della chiesa.

L'irregolarità che ne risulta, sia nella rappresentazione in piante e sezioni, che in quella volumetrica, non è quindi un elemento marginale o, peggio, da scartare, ma anzi una caratteristica che deve essere colta e valorizzata.

La possibilità di sovrapporre in trasparenza i rilievi dell'esterno e dell'interno ha portato a considerare e verificare, nel caso di studio in oggetto, alcune interpretazioni funzionali dell'edificio, vale a dire la discussione se l'originaria articolazione interna di Santa Croce fosse in un unico e ampio volume $o$ in due livelli che furono poi divisi dall'inserimento della volta, come spesso è stato sostenuto. La parziale esistenza di una risega a livello della volta, visibile in alcuni piani di sezione, sembrerebbe escludere che in origine vi fosse un unico volume, perché essa interrompe la continuità delle pareti interne. Ė quasi certo che una differenza così esigua e per di più non presente su tutta la pianta non sarebbe stata evidenziata da un rilievo di tipo tradizionale (fig. 8).

La sperimentazione riguardante la chiesa di Santa Croce ha visto le fasi di rilievo metrico e fotografico svolgersi contestualmente. II confronto tra le proiezioni ortografiche ottenute e i rilievi eseguiti negli anni '30, poi integrati con metodi tradizionali in occasione degli ultimi lavori di sistemazione dell'area, non è un semplice esercizio di comparazione metrica e di ricerca della precisione (peraltro, non privo di motivi di interesse), ma un'occasione importante per verificare in quali aspetti il rilievo effettuato con laser scanner 'produca' informazioni utili all'interpretazione dell'architettura storica.

Fig. 8. II confronto tra il 'modello ideale' e la sua effettiva costruzione; dall'analis grafica tradizionale con lo studio della geometria e de rapporti di proporzione alle proiezioni ortografiche del rilievo 3D laser scanning che rappresentano il costruito e e sue imperfezioni.
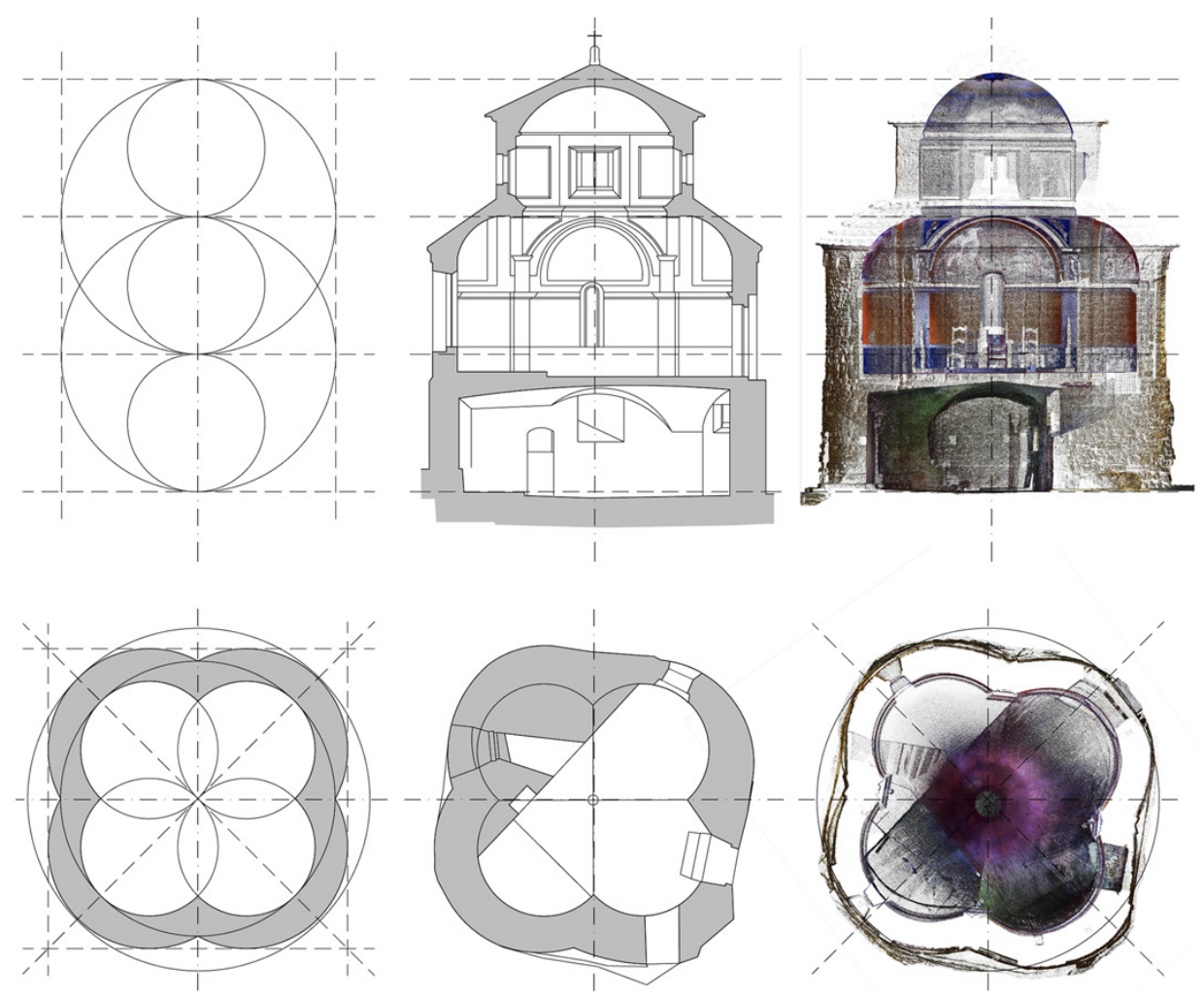

\section{Epilogo}

Ho chiesto al professor Mario Manganaro di venire a Bergamo molte e molte volte, ma lui ha sempre declinato il mio invito. Ero diventato grande, non più un giovane studente ma un maturo allievo che doveva percorrere da solo la sua strada. Negli anni passati a Messina 
avevo seguito il professore nei suoi studi, senza sviluppare autonomamente una mia linea di ricerca; con il mio trasferimento nella città orobica, per prendere il posto di Sereno, era giunto il tempo di coltivare autonomamente le mie attitudini.

Il professor Mario Manganaro ha comunque rappresentato, in tutti quegli anni, la figura - quasi paterna - con cui confrontarmi e a cui chiedere sempre consiglio. Ci sentivamo regolarmente il sabato mattina, lui lo passava nel suo studiolo con la vetrata che traguardava lo Stretto ed io nel mio ufficio a Dalmine di fronte alla omonima fabbrica; non appena avevo la possibilità di tornare a Messina lo andavo sempre a trovare. Una mattina mi raccontò di essere passato da Bergamo per rientrare a casa dopo un ricovero in ospedale a Pavia. Avevano dormito in un hotel in città per ripartire presto la mattina dall'aeroporto di Orio al Serio.

Aveva disegnato su un piccolo taccuino da viaggio lo skyline dei monti visto dall'aeroporto, credo l'unico disegno della mia nuova città. Uno schizzo con pochi tratti veloci e sofferenti, espressione della volontà di non abbandonarsi al destino ma di voler sempre lottare. Fu l'ultima volta che lo vidi, lo ricordo in quell'ultimo incontro affaticato e molto indebolito ma sempre generoso nelle parole e con il cuore... dopo pochi mesi ci ha lasciati.

\section{Note}

[I] Gli autori ringraziano la famiglia Manganaro nella figura della moglie Giovanna e dei figli Francesco e Marina, a cui va un particolare plauso, per l'instancabile dedizione all'archivio personale del professore e di tutte quelle manifestazioni ed eventi di cui hanno garantito - con la loro curatela - non solo il mantenimento del ricordo, ma la prosecuzione del suo straordinario e complesso pensiero. II saggio è frutto del lavoro congiunto degli autori che lo hanno discusso insieme in tutte le sue parti; la redazione del primo paragrafo si deve a Sereno Innocenti e prologo, interludio, epilogo e secondo paragrafo ad Alessio Cardaci. II paragrafo "il rilievo 3D della chiesa di Santa Croce tra conoscenza metrica e storica" del presente saggio è una rivisitazione di due precedenti articoli: Cardaci,Versaci 2013; Cardaci,Versaci, Gallina 2013.

\section{Riferimenti bibliografici}

Aikema Bernard, Schellinks Willem (1983). Viaggio al sud (I ed. I 664 - 1665). Roma: Edizioni dell'Elefante.

Angelini Luigi (1940). Scoperte e restauri di edifici medievali in Bergamo alta. In Palladio; rivista di storia dell'architettura. IV/1940, pp. 35-43.

Angelini Luigi (1963). I lavori compiuti per il piano di risanamento di Bergamo alta (1 936-1943, 1950-1 960). Bergamo: Stamperia Conti.

Aricò Nicola (1999). Illimite Peloro. Messina: Mesogea Editrice.

Calzana Pino, Caccia Bruno (2008). Attorno a Santa Croce. In La rivista di Bergamo, n. 54/2008.

Cardaci Alessio,Versaci Antonella (20I3). Image-based 3D modeling vs laser scanning for the analysis of medieval architecture: the case of St. Croce church in Bergamo. In ISPRS - The international archives of the photogrammetry, remote sensing and spatial information sciences, 40-5/w2.

Cardaci Alessio, Versaci Antonella, Gallina Dario (20I3). Laser Scanner 3D per la catalogazione dell'Architettura Medioevale: la chiesa di Santa Croce in Bergamo. In Archeologia e calcolatori 24/20 I3, pp. 209-229.

Fortunati Maria, Vitali Mariagrazia (2000). Bergamo, cappella di Santa Croce. Le strutture ipogee tra età romana e medioevo. In Notiziario della soprintendenza per i beni archeologici della Lombardia, 20 I 0/201 I, pp. 199-202.

Ghiroldi Angelo (2007). La cappella di Santa Croce in Bergamo. In Fortunati Maria, Poggiani Keller Ruggiero (a cura di). Storia economica e sociale di Bergamo. I primi millenni, dalla preistoria al medioevo. Bergamo: Fondazione per la storia economica e sociale di Bergamo. pp. 534-538.

Venanzio Ortensia (1959). Costruzioni romaniche a sistema centrale nel bergamasco. In Arte Lombarda IV/I, pp. 29-35.

Autori

Alessio Cardaci, Università degli Studi di Bergamo, alessio.cardaci@unibg.it

Sereno Innocenti, Università degli Studi di Brescia, sereno.innocenti@unibs.it

Per citare questo capitolo: Cardaci Alessio, Innocenti Sereno (2020). Dal faro per il mare al pozzo per il cielo: la chiesa di Santa Croce a Bergamo nella memoria di Santa Maria della Grotta a Messina/From the lighthouse to the sea to well for the sky: the church of Santa Croce in Bergamo in the memory of Santa Maria Della Grotta. In Arena A., Arena M., Brandolino R.G., Colistra D., Ginex G., Mediati D., Nucifora S., Raffa P. (a cura di). Connettere. Un disegno per annodare e tessere. Atti del $42^{\circ}$ Convegno Internazionale dei Docenti delle Discipline della Rappresentazionel Connecting. Drawing for weaving relationships. Proceedings of the 42th International Conference of Representation Disciplines Teachers. Milano: FrancoAngeli, pp. 1902-1923. 


\title{
From the Lighthouse to the Sea to Well for the Sky: the Church of Santa Croce in Bergamo in the Memory of Santa Maria Della Grotta
}

\author{
Alessio Cardaci \\ Sereno Innocenti
}

Abstract

The research on the chapel of Santa Croce in Bergamo and Santa Maria della Grotta in Messina offers, in this essay, the opportunity to remember and pay homage to Professor Mario Manganaro, a generous designer who profoundly influenced the lives of the two writers. A strange connection of fate that links the two cities and the authors to the great master. Mosaic tiles that intertwine and knot in the design of two important architectures, understood and documented through the gaze of the designer 'from life' and the 'contemporary' detector which integrates traditional graphic analysis with the potential offered by 3D laser scanning systems and image based reconstruction.

Keywords

drawing, survey, graphic analysis, virtual reconstruction, Medieval architecture, Luigi Angelini.
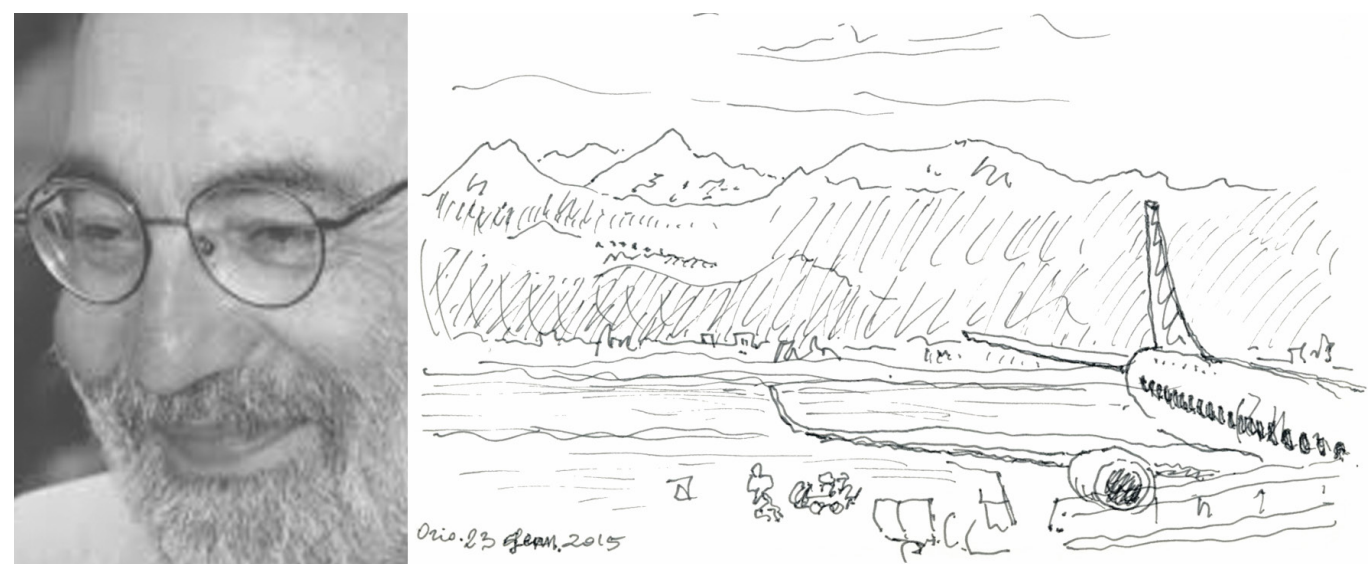


\section{Prologue}

Here we talk about a journey, a journey that lasted over twenty years. A long road was taken at the sign of the drawing to remember a great master, who by linking Messina, the city of the Strait, to Bergamo, the ancient fortress of the Serenissima, involved the two authors influencing their lives and fate. Memory, more than a scientific essay, wants to be a tribute to celebrate Professor Mario Manganaro, a generous and incomparable person.

My and Sereno's experience, through two shared examples in the teaching of an expert designer, wants to testify the peculiarities of a specific school of thought that bases survey on direct contact with the built and not only on the indirect observation of the eye electronic sensor. A reflection on the evolution of the discipline in a time excursus in the transition between the old and the new millennium.

Fig. I. Drawings of the Messina coast:

a) view towards Capo Peloro:

b) view of Stretto di

Messina near church of

Santa Maria della Grotta

(drawings by Mario

Manganaro e Sereno Innocenti).
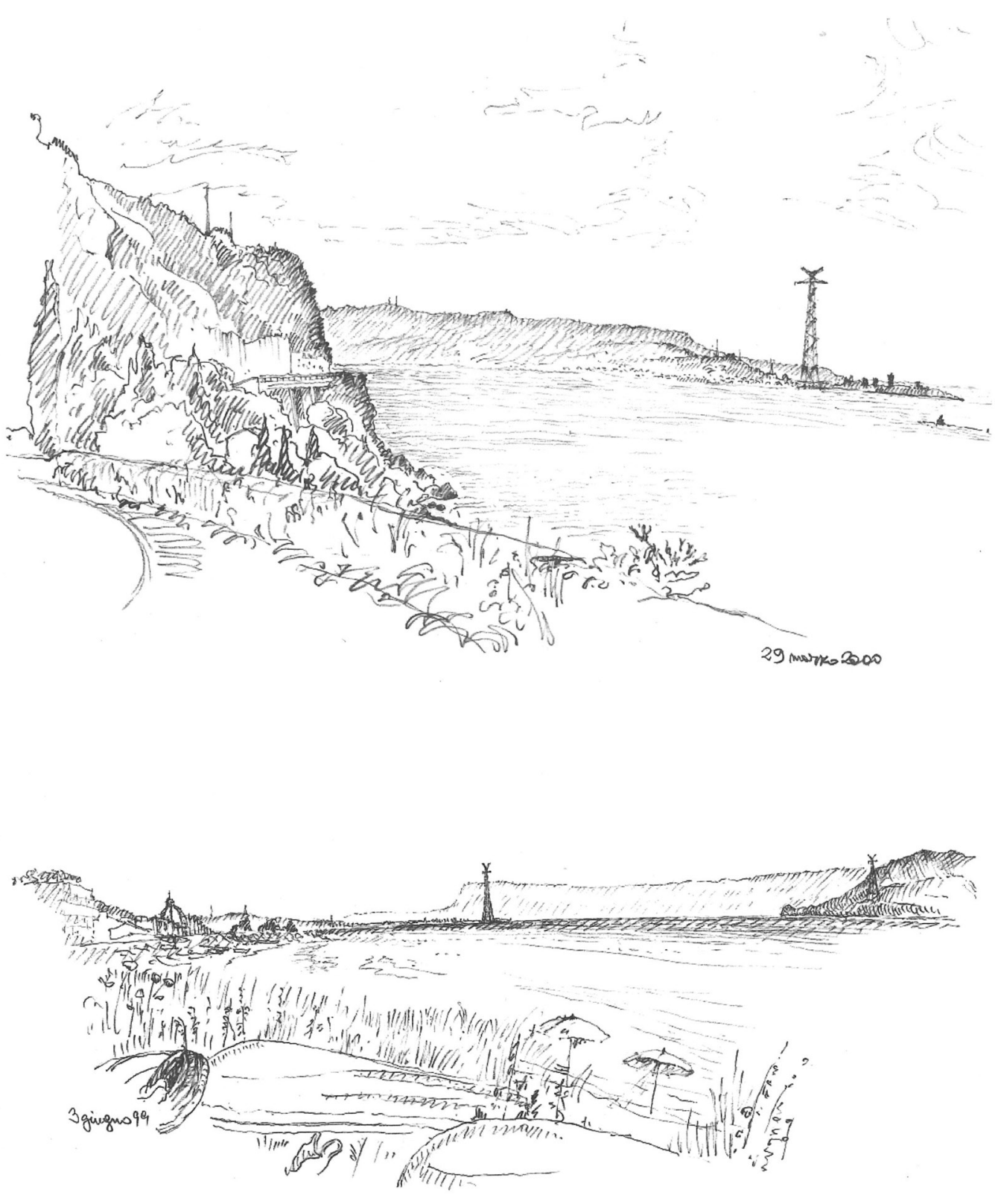


\section{A lighthouse for the sea and a well for the sky}

During my appointment at the engineering faculty of Messina, I was the holder of the course of landscape representation and undertook a study on the coast of the Sicilian city, including from the port to Capo Peloro; the last offshoot, the border point of the island, the limitless [Aricò 1999]. From the first inspections made individually with a motorcycle or on the car together with professor Mario Manganaro, along the splendid coast of Messina, I realized that something particularly cathartic, not only changed the scene, but in some way conditioned perception, path and atmosphere (figs. I a, I b). In fact, in Grotte, the church of Santa Maria transforms its circular plan into a sort of 'cardan joint', an ideal mechanism in the area to underline and connect the path of the coast, from its morphological genesis, which can be realized in the area port, up to Capo Peloro. Upon reaching the building, you have the feeling of being in front of a lighthouse. The architectural artifact signals of its presence an event of mutation of the territory, while its intended use transforms it into a beacon of faith; visible also and above all from the sea, in that particular context, the church-lighthouse finds its genius loci. Different and controversial were the design attributions and the dating of the church, which has not gone unnoticed over the centuries to its varied designers. Filippo Juvarra already sensed the importance of the role, to the point of masterfully illustrating its vestige in an Ink view of Messina and urban planner with the new Royal Palace (National Library, Turin) and Willem Schellinks, in I664, it also illustrates with two different points the coast where Santa Maria delle Grotte degrades its airy staircase, which in time disappeared up to the shoreline [Aikema 1983]; in one view from the church towards the sickle and the other towards Capo Peloro (Osterreichische Nationalbibliothek, Vienna). On the other hand, it remains irrefutable that starting from the I6th century, a small monastery named after the Virgin Mary called the cave (figs. Ic, Id) existed in the same site, being reconstructed on the ruins of the pagan temple of Diana; therefore, the area had already been sacralized by Christians for the cult of the Madonna (fig. 2).

After the three-year confirmation period, I was called to transfer to the engineering faculty in Bergamo, with a chair in the first-year course in Drawing. It is my habit, now consolidated over time to work with students on small themes, to design architectures of contained dimensions, easily accessible to be detected with simple metric tools and to be returned manually by basic geometric design. The small church of Santa Croce, of which the excavation works were underway, seemed to have been chosen as necessary. So, I took the

Fig. Ic. Drawings of the Messina coast: views and stretches of the church of Santa Maria della Grotta (drawings by Mario Manganaro e Sereno Innocenti).

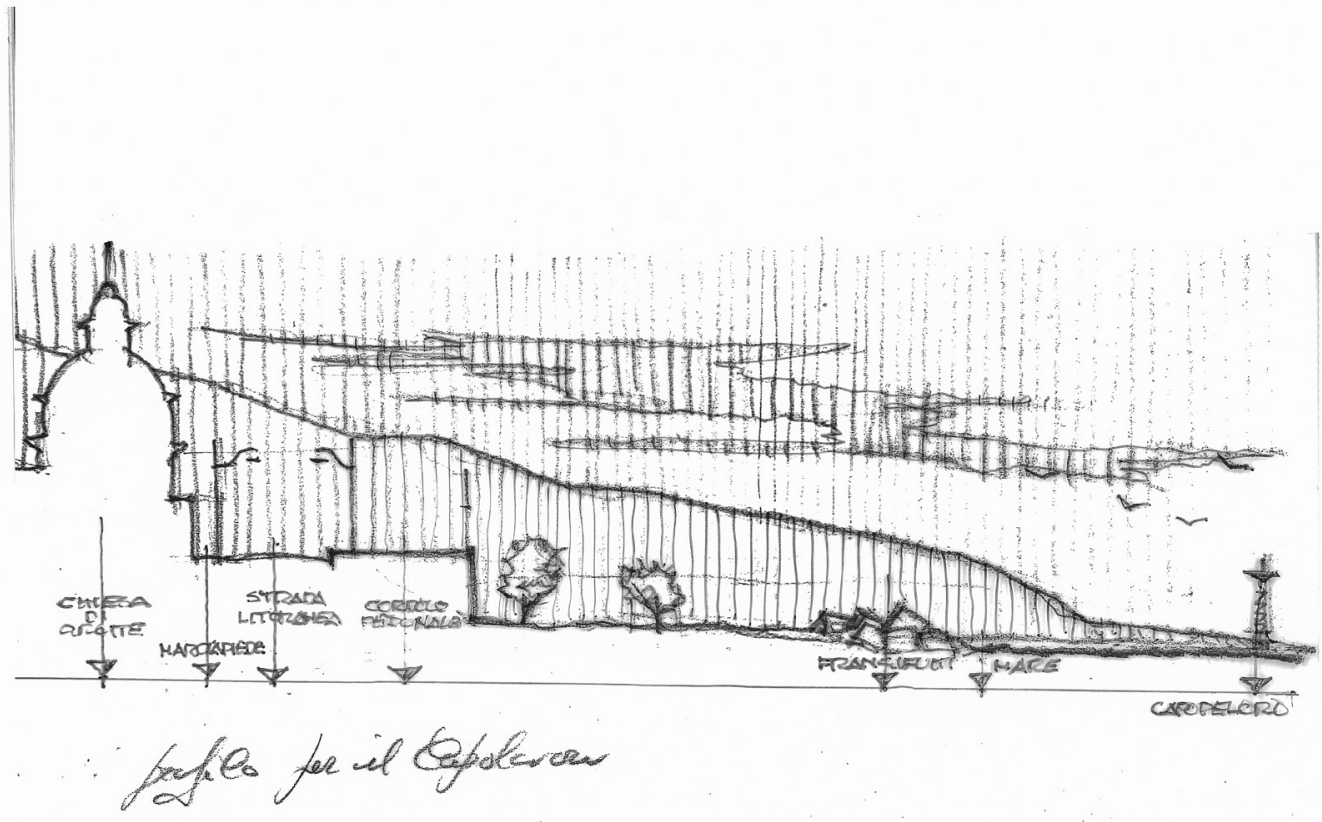


Messina experience with professor Mario Manganaro with me, so with the students, we embarked on a short trip to the historic centre of the city to the church. We tried to record everything, sensation and emotions. We worked for metaphors, symbols and even for real architectural oxymorons, before taking any measurements, before rolling out the tape measure or assembling the metric rods (in the real bamboo cane), which today as they should be used for the first approach with architecture and above all when this must be aimed at its basic representation for knowledge, as Giovanni Michelucci claimed "to touch the stones of the walls with your hand". The survey did not exclude which were the access routes to the site, with the related floors and structures (figs. 3a, 3b). But it was in the notes of this short trip to the curia that the feelings of the church were recorded in the notebook. The construction site in progress, with its scaffolding infrastructure, transformed it dreamily into another 'theatre of the world' and in the memory of Aldo Rossi's project, the metaphor was evident. Similar reflections led to comparing in its planimetric context the small church to a sort of compositional symbiosis similar to that with which Bernardo Rossellino was able to contextualize the imperious buildings in the square of Pienza, around the historic 'urban furniture' represented by the well. In this succession of these transversal reflections, we even came to the extreme comparison of comparing the captivating circular volume of

Fig. Id. Sketch near church of Santa Maria della Grotta (drawing by Mario Manganaro e Sereno Innocenti).

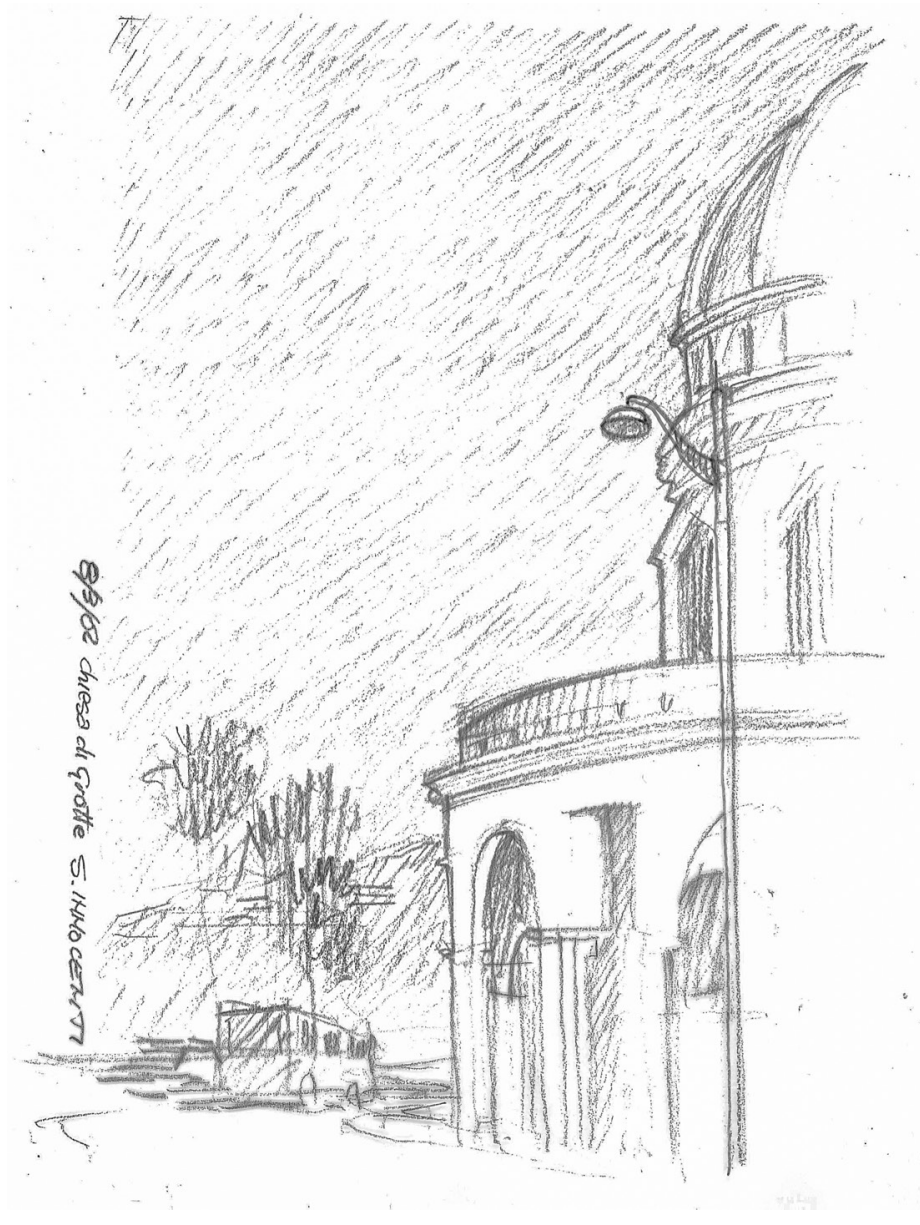

Santa Croce in the cinematographic epilogue of Akira Kurosawa then later taken up by the architect Carlo Simi in the sets of the dollar trilogy for the director Sergio Leone (fig. 4). With its central plan, Santa Croce takes us back to the cult of the circle, to the solar cult of the primitives or in current religions, in myths or dreams, in the mandala motifs of Tibet, in the astrolabes of the first astronomical conceptions, but above all, it is a symbol of life. The scripture narrates something similar also concerning Buddha, who at the moment of birth 
surmounts the lotus flower to contemplate the ten directions of space. The lotus flower has eight rays, but the dozen completes the one towards the earth and the one towards space. The plan of the church, therefore, consists of an octagonal layout, whose radial and compositional axes, start from the most barycentric area of the courtyard delimited by the body of the building of the ancient episcope with the curia room. Thus, it is possible to venture the hypothetical reading of ten compositional axes of space: eight traceable from the lobes and two from the symmetrical directions of the sky and the earth. Earth and sky are thus connected in the Christian faith and materialized in the walls of the church in irregular stone blocks with a hollow split face. This impalpable junction is however perceivable reaching the site through the suggestive paths that from Bergamo's historical centre (Piazza Vecchia) lead through the cathedral, the palace of reason and Santa Maria Maggiore to discover the courtyard of the bishop's curia. Immediately it is perceptible how the buildings surrounding the small church influence its coexistence inside the courtyard and although it is clear that the building was the baptistery of the city before becoming a bishop's chapel, its zenithal view or simple cartographic observation, it can let us suppose that the area occupied by Santa Croce could be the one destined to a well (of faith)... a well for heaven!!!

Fig. 2. The church of Santa Maria della Grotta in a postcard from the early twentieth century.

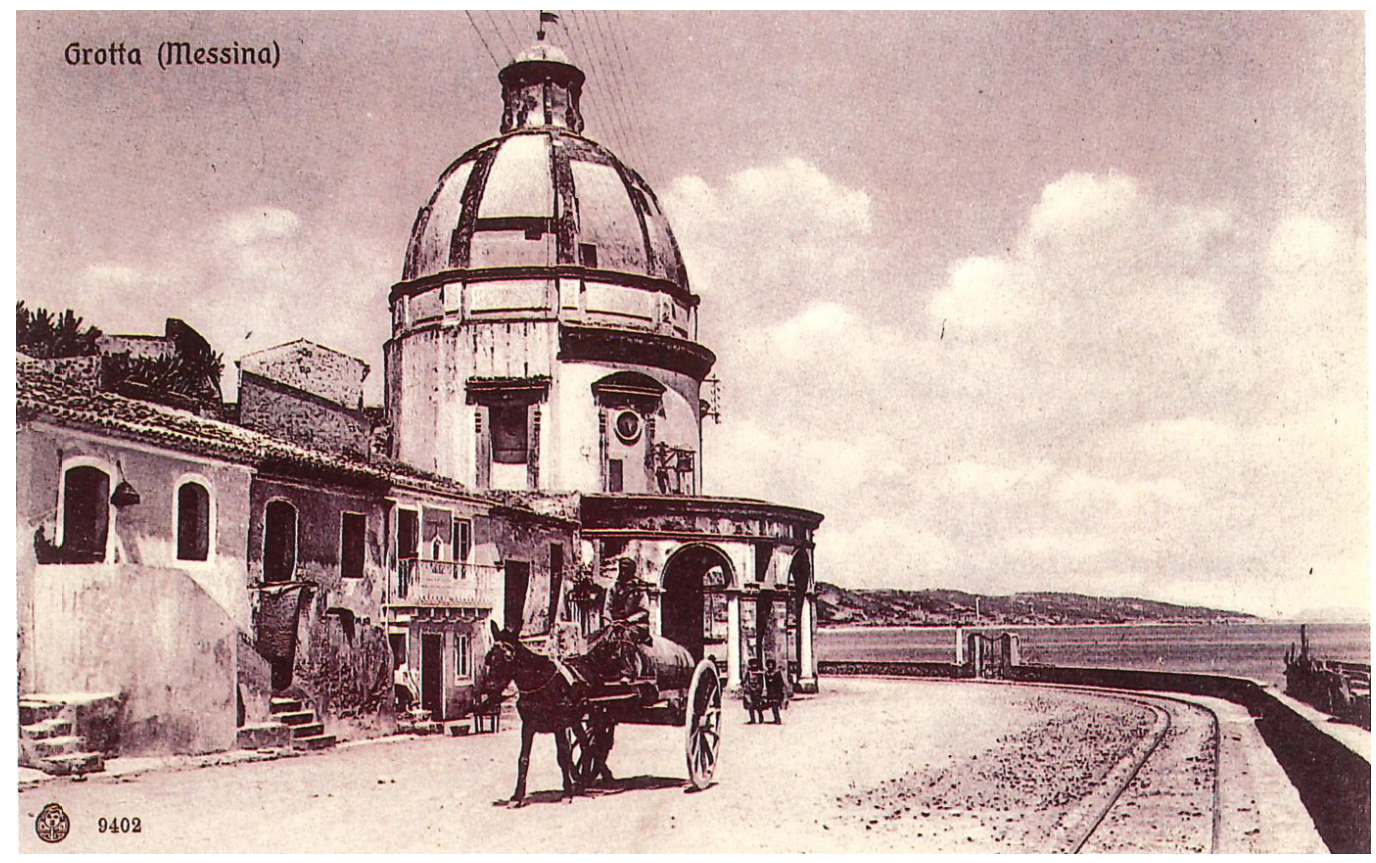

\section{Interlude}

Professor Mario Manganaro approached me to the survey and taught that it is an instrument for understanding the past, important for living the present and for projecting towards the future; architectures tell their story, just listen to them. Through direct observation, the designer reads the sign of time and its metamorphoses on buildings, therefore conserve and documents their knowledge through the graphic sign. The professor was a man of tradition who, although he knew the modern techniques of indirect acquisition with sensors, did not particularly love them. I, then a young researcher fascinated by new tools and nascent return software, have never shared his point of view and, sometimes, feeling almost hindered in my research aspirations. Only over the years have I understood his teaching, appropriating it and evolving it through the integration of traditional graphic analysis of the potential offered by $3 \mathrm{D}$ laser scanning and image based reconstruction systems. 


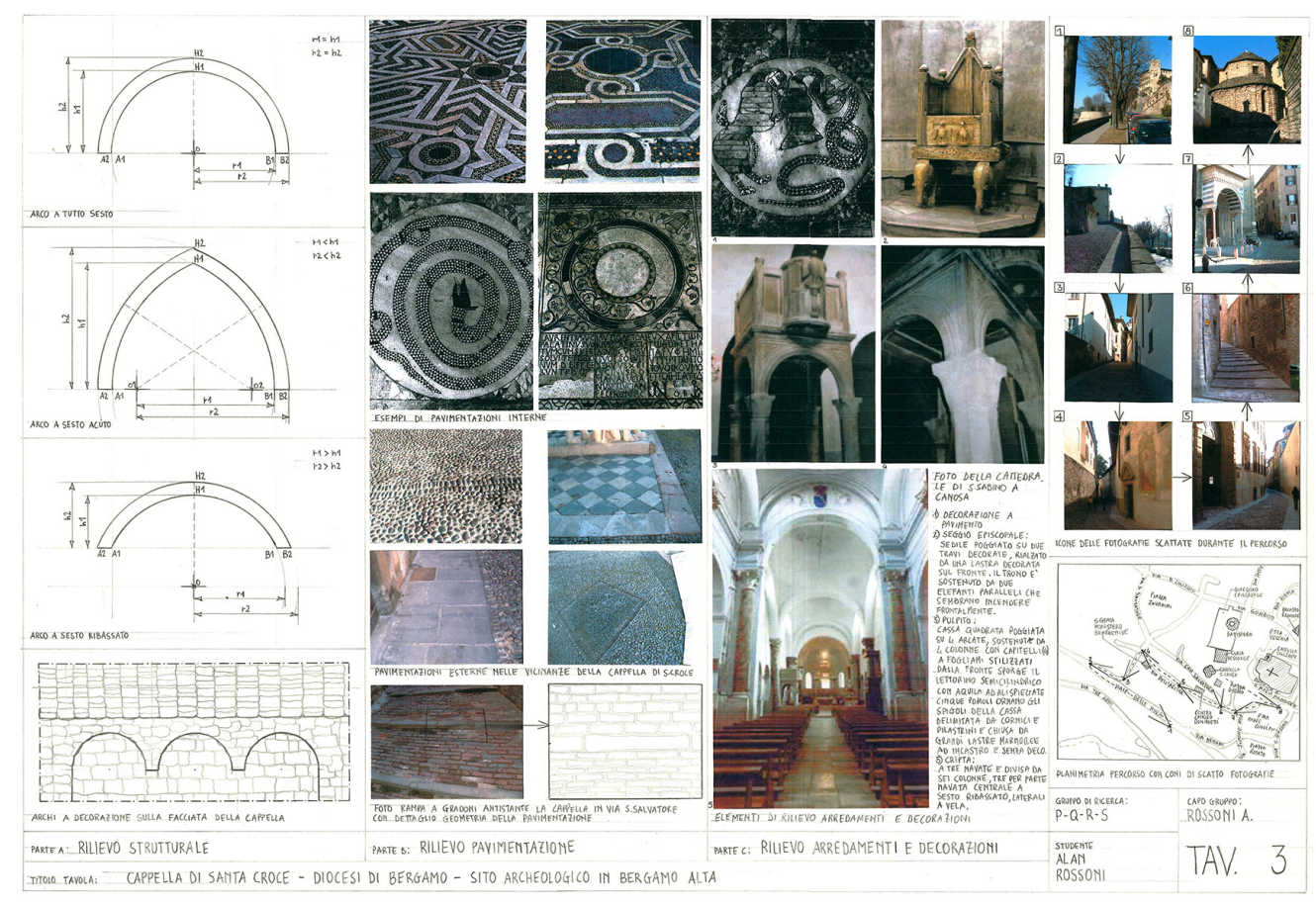

Fig. 3. Synoptic tables by the students of Piazza

Vecchia and the curch of

Santa Croce a Bergamo:

a) floorings;

b) structures

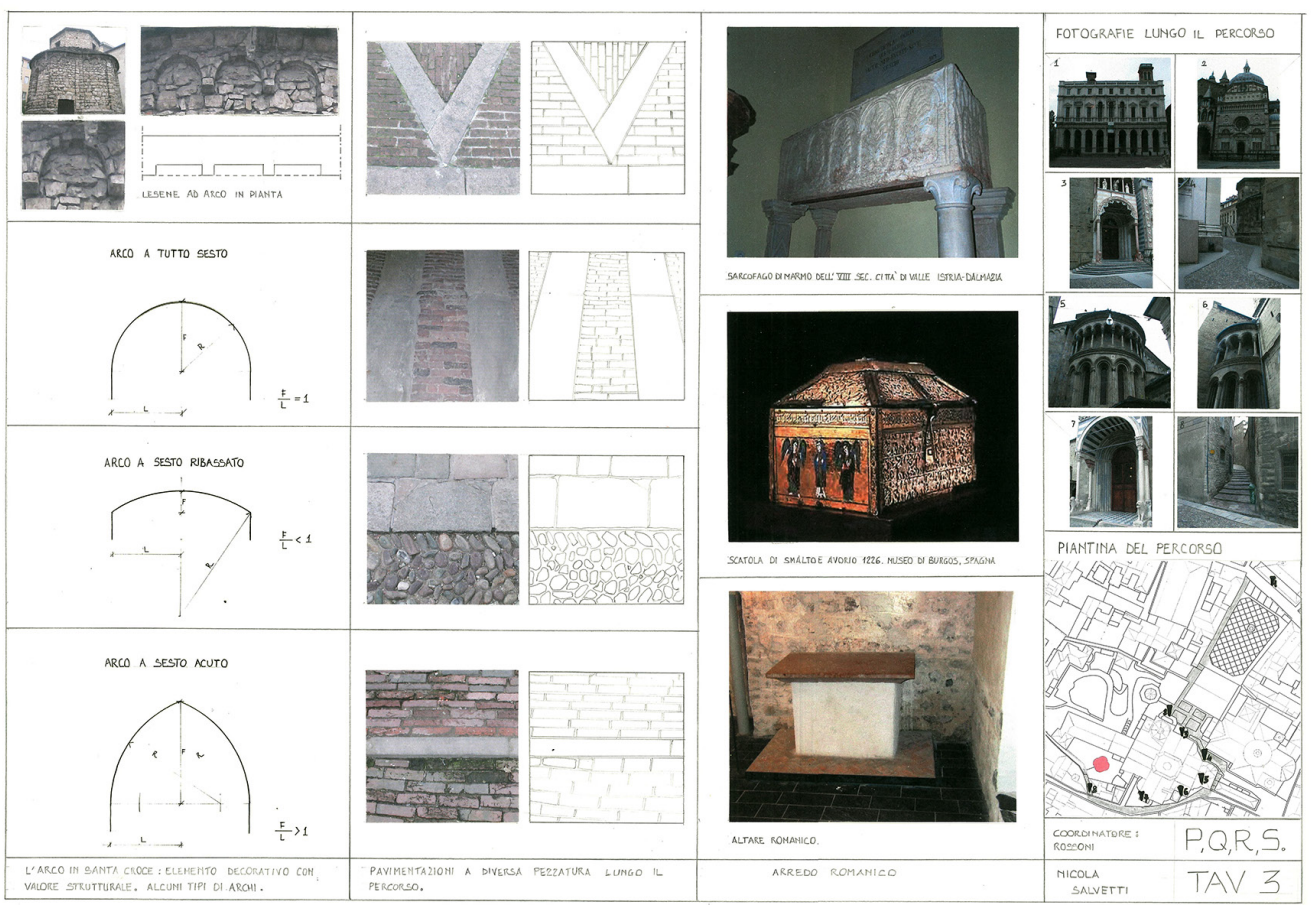




\section{The 3D survey of the church of Santa Croce between metric and historical knowledge}

The research activity summarized here concerns the church of Santa Croce in Bergamo; aimed at the restoration of the work, it's intended to provide, through the 3D survey, that contribution in terms of historical, geometric, constructive and stratigraphic knowledge, which appears substantial for the conservation, cataloguing and enhancement operations (fig. 5).

The small Romanesque chapel is located in a courtyard between the Bishop's Curia and the cathedral of Santa Maria Maggiore; it is characterized by a particular four-lobed plan and develops on two main levels, devoid of internal communication because they are divided by a vaulted system, and a lantern [Fortunati, Vitali 2000].The upper floor is punctuated by thin columns connected by a series of three small brick arches and equipped with two splayed single lancet windows; the lower one is instead without pilasters, has a door on the level of the medieval decking and two rectangular windows.

The chapel was completely highlighted in the 1930s by Luigi Angelini as part of his rehabilitation plan for the upper town [Angelini 1940; Angelini 1963]; due to the addition of modern buildings of various kinds, it was almost hidden and therefore, in its overall configuration, unknown; during the restorations, the courtyard floor was probably lowered, the roofs were completely redone and all the plaster was removed, which only a few small fragments

Fig. 4. Schemes of the restoration (then underway), metaphorical, dreamlike and comparison impressions during the drawing of the life of Santa Croce inside the construction site in October 2005 (drawings by Sereno Innocenti).
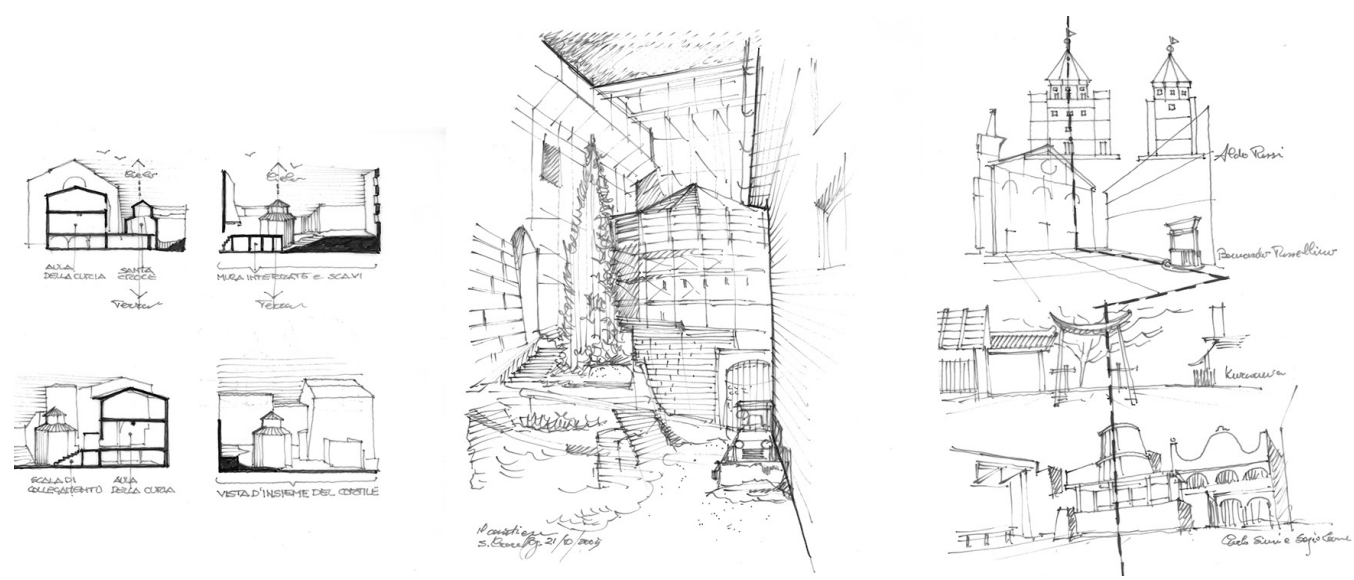

remain today. The joints of the external masonry were completely 'reworked' in concrete and the integrated masonry with mimetic intent that still makes reading and stratigraphic interpretation still difficult (fig. 6).

The particular four-lobed plan, in the opinion of some scholars, finds its most pertinent comparisons in baptismal buildings; this similarity, together with the presence of the aqueduct, has led many to speculate on a baptismal function, despite the lack of evidence in the documentation and - above all - in the absence of traces of the baptismal font [Venanzio 1959; Ghiroldi 2007].

The church of Santa Croce derives from a rather complex composition of volumes that have generated a building that is by no means trivial and probably built with many technical difficulties (for example, the insertion of the asymmetrical vault of the ground floor, and the management of the architectural connection by the four tiburium lobes above the second level). It is evidently an initial idea of space attributable to construction with multiple axes of symmetry, based on a central (the vertical axis of the building) for which the four circumferences that draw the four-lobed plan are tangent, but the construction phase, while roughly following this approach, it has not rigorously respected it: the 'circumferences' are round with variable radius and curvature, the alignments appear random, not regular straight seg- 


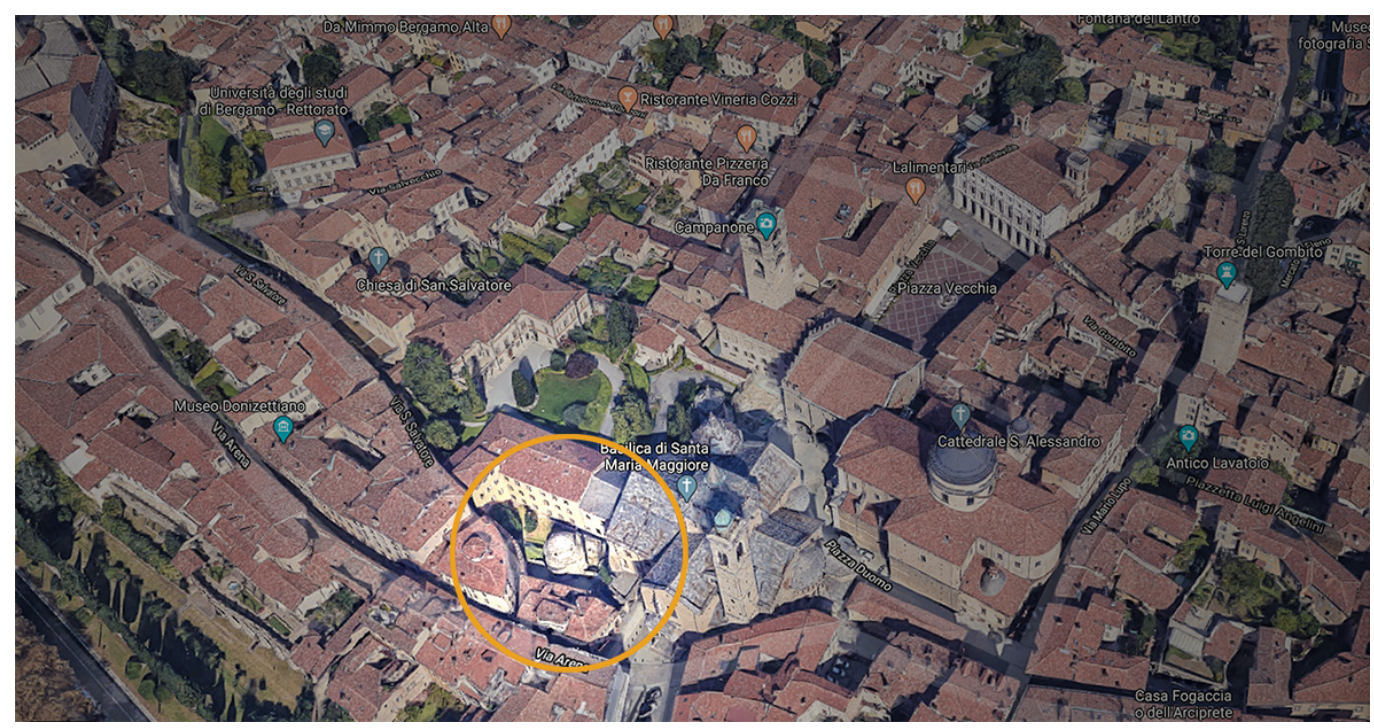

ments but uncertain and undulating lines. Above all, the existence of several different set-aside areas is evidence of adjustments during construction, aimed at correcting the volumes of the building in its early stages of construction. Finally, the same unitary idea of space that binds the plan and the elevated part because of a ratio of $2 / 3$, inside is contradicted by the vault of the attic that divides the church into two rooms [Cardaci 20 I3; Cardaci et al. 20 I 3]. Faced with this contrast between geometric model and realization, it is natural to wonder what the role of the 'master builder' was in the Middle Ages and which influenced it on the construction site. It is precise because of the discrepancies between the ideal model and the actually constructed building, that it was decided to read it through the 'automatic survey' since the traditional survey, both direct and instrumental, leaves the detector a possibility interpretative of geometry, mediated by its knowledge and culture, which are inevitably far from the medieval symbolic and analogical mentality. The choice of the points to be measured (that is, the selection between what is to be measured and what, on the other hand, can be overlooked) is manifested from the initial stages of the design of the eidotypes, essential sketches in the traditional survey to report the measurements of time after time. Furthermore, in the schematization of the plans, sections and elevations, an idea of regularized and hierarchical geometry between the parts considered most important is already configured. Conversely, automatic surveying is characterized by a sort of inability of the measuring in-

Fig. 6. The church of Santa Croce, before and after Luigi Angelini's restorations, and today.
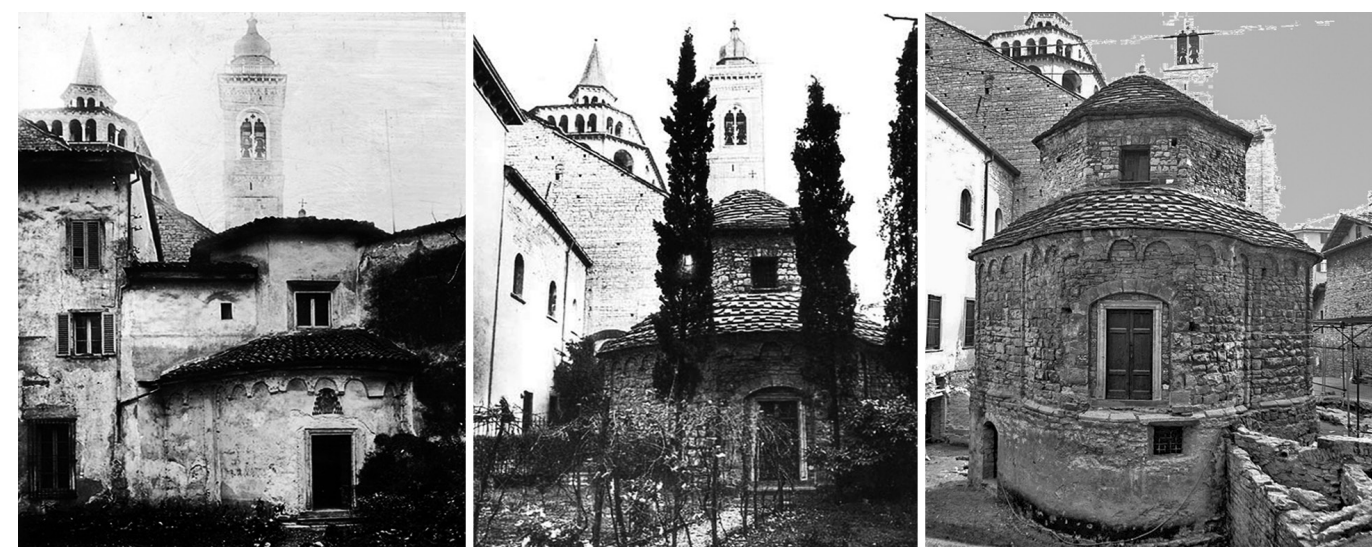
strument to make 'intelligent' choices. The scanning laser detects everything that is around him and visible to him, without actually 'seeing' what he measures and without distinguishing the parts of the building by importance. Each element is simply interpreted as a sequence of points spaced more or less constant between them. Ultimately, an automatic acquisition tool does not have the human ability to interpret shapes and geometries and is therefore capable of returning orthographic and/or cross-section projections, such as simple sequences of points, not conditioned by a perhaps erroneous and previous interpretation of the spatiality of the monument. A scan is a 3D representation of the object: a solid photograph that allows you to obtain an image in which each pixel also provides the spatial position of each detail captured by the instrument.

A more accurate survey also explains the construction irregularity of the building, which must not be considered the 'degradation' of a design idea due to the inaccuracy of the accidental reality of the construction site, but a peculiarity of the medieval buildings (fig. 7). The rectification, which is usually applied in the graphic representation of structures that are devoid of almost of straight walls or rigorous symmetries, are really misleading for Romanesque buildings, whose regularity is apparent, in particular for those of the first Romanesque style, which are characterized by executions and technical solutions that are still rather uncertain. It is therefore clear that these progressive adjustments of the profile of the risers, if correctly
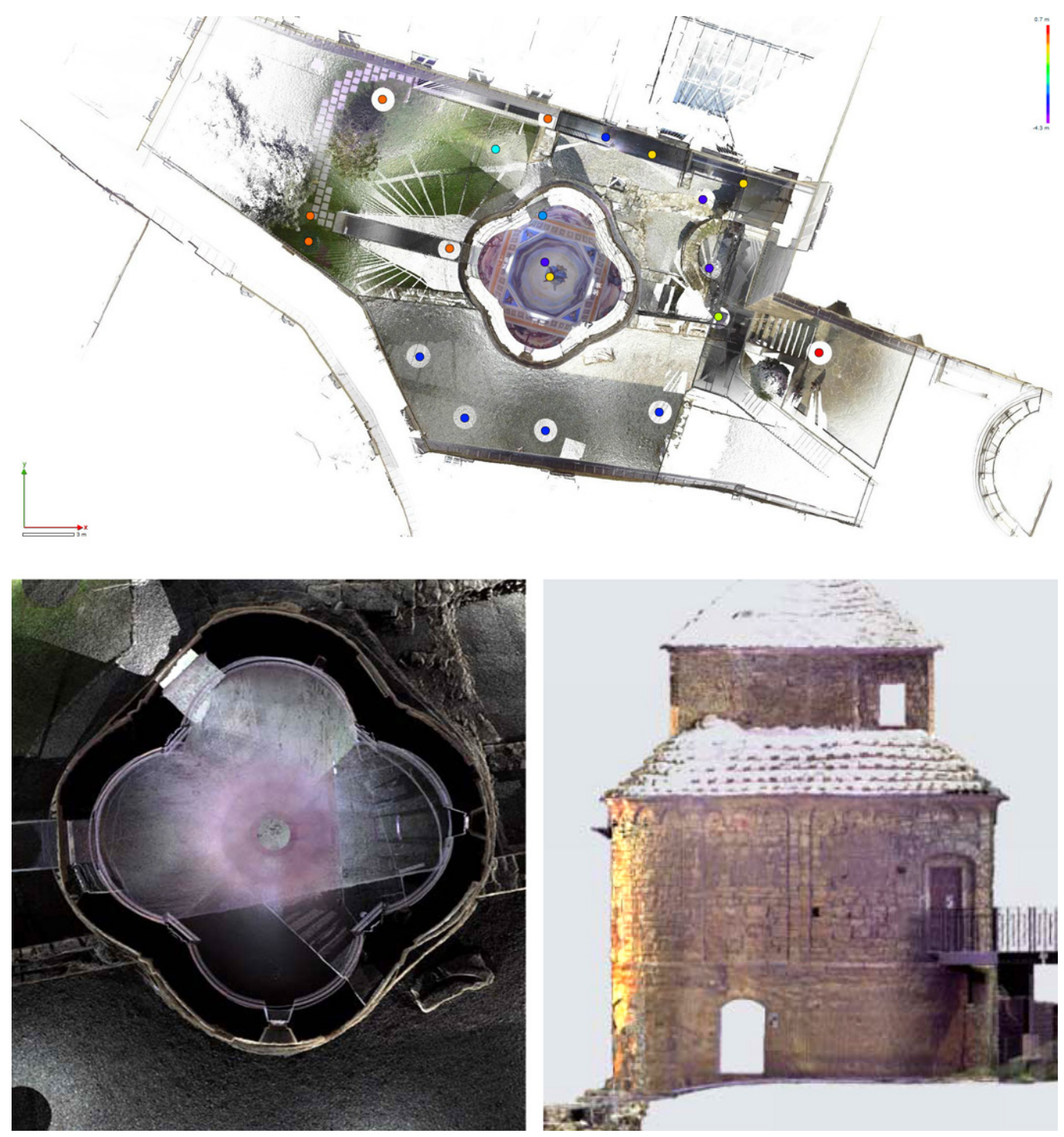
detected and represented, are elements that contribute to the dating and understanding of the church.

The resulting irregularity, both in the representation in plans and sections, and in the volumetric one, is therefore not a marginal element or, worse, to be discarded, but rather a characteristic that must be grasped and enhanced.

The possibility of transparently overlapping the external and internal survey has led to consider and verify, in the case study in question, some functional interpretations of the building, namely the discussion of whether the original internal layout of Santa Croce was in a single large volume or in two levels which were then divided by the insertion of the vault, as has often been claimed. The partial existence of a ledge at the level of the vault, visible in some section planes, would seem to exclude that originally there was a single volume, because it interrupts the continuity of the internal walls. It is almost certain that such a small difference and not present on the whole plant would not have been highlighted by a traditional survey (fig. 8).

The experimentation regarding the church of Santa Croce has seen the metric and photographic survey phases taking place simultaneously. The comparison between the orthographic projections obtained and the surveys carried out in the 1930s, then integrated with traditional methods on the occasion of the last works of the arrangement of the area, is not a simple exercise of metric comparison and search for precision (moreover, not without reasons of interest), but an important opportunity to verify in which aspects the laser scanner survey "produces useful information for the interpretation of historical architecture.

Fig. 8. The comparison between the "ideal model" and its constructive construction; from the traditional graphic analysis the orthographic projections of the $3 \mathrm{D}$ laser scanning.
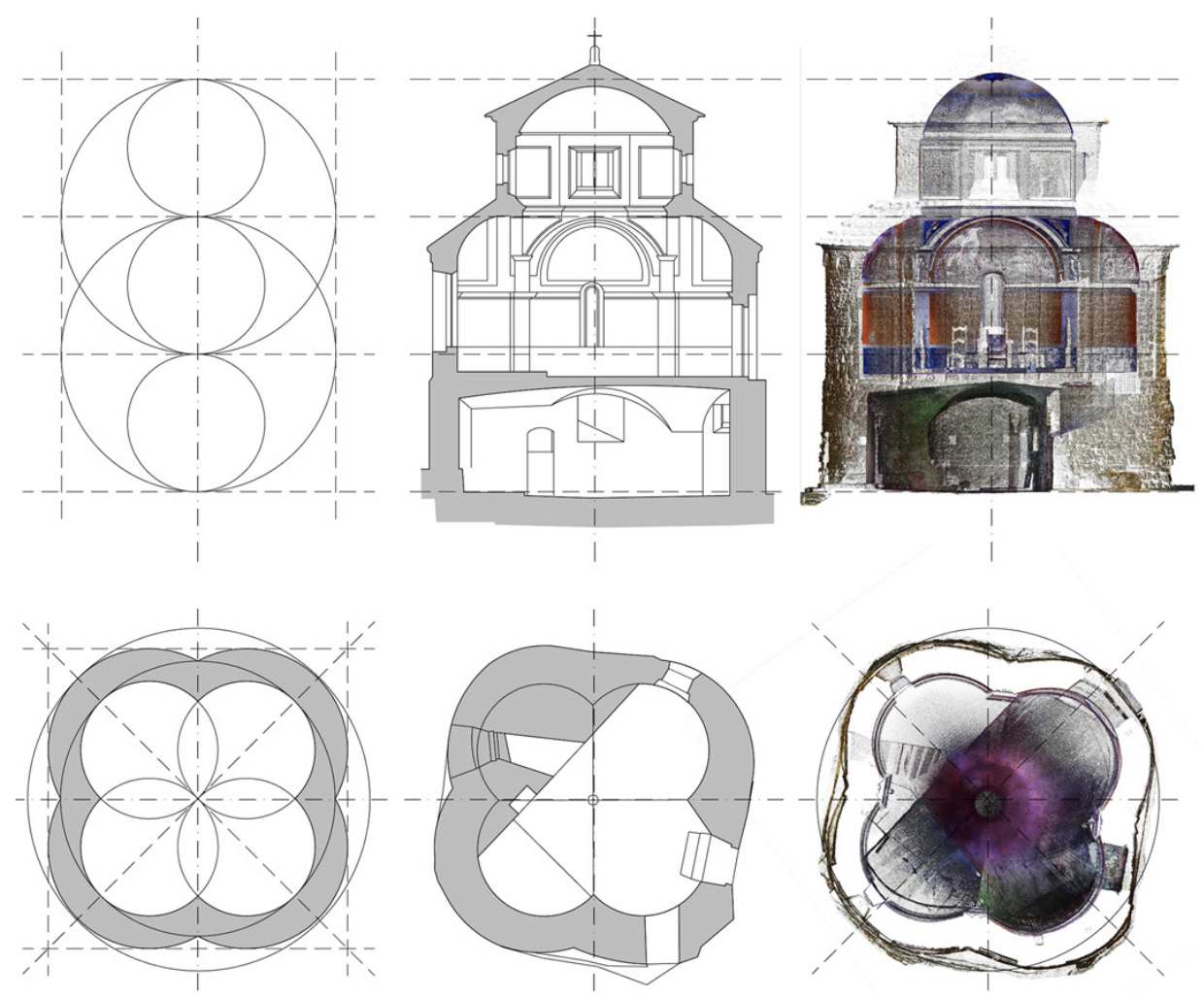

\section{Epilogue}

I asked Professor Mario Manganaro to come to Bergamo many and many times, but he has always declined my invitation. I had 'grown-up' no longer a young student but a mature student who had to go his own way. In the years spent in Messina I had followed the pro- 
fessor in his studies, without independently developing my line of research; with my transfer to the Orobic city, to take the place of Sereno, the time had come to cultivate my attitudes independently.

In all those years, Professor Mario Manganaro has always represented the figure -almost paternal- with whom to confront me and to always ask for advice. We met regularly on Saturday mornings, he spent it in his study with the stained glass window that crossed the Strait and me in my small office in Dalmine in front of the homonymous factory; as soon as I had the opportunity to return to Messina I always went to visit him. One morning he told me that he had come to Bergamo, before returning home after being hospitalized in Pavia. They had slept in a hotel in the city to leave early in the morning from Orio al Serio airport. He had drawn the skyline of the mountains seen from the airport on a small notebook, I think the only drawing of my new city. A sketch with a few fast and suffering traits, an expression of the desire not to abandon oneself to destiny but to always want to fight. It was the last time I saw him, I remember him in that last tired and very weakened meeting but always generous in words and heart ... after a few months, he left us.

\section{Notes}

[I] The authors thank the Manganaro family in the figure of his wife Giovanna and their sons Francesco and Marina, to whom special applause goes, for the tireless dedication to the professor's archive and for all those manifestations and events they have guaranteed - with their curation - not only the maintenance of the memory but the continuation of his extraordinary and complex thought. The essay is the result of the joint work of the authors who discussed it together in all its parts; the editorial staff the first paragraph is due to Sereno Innocenti and prologue, interlude, epilogue and second paragraph to Alessio Cardaci. The paragraph "the 3D survey of the church of Santa Croce between metric and historical knowledge" of this essay is a review of two previous articles: Cardaci,Versaci 20 I3; Cardaci, Versaci, Gallina 20 I 3.

\section{References}

Aikema Bernard, Schellinks Willem ( 1983). Viaggio al sud (I ed. I 664- I 665). Roma: Edizioni dell'Elefante.

Angelini Luigi (1940). Scoperte e restauri di edifici medievali in Bergamo alta. In Palladio; rivista di storia dell'architettura. IV/I 940 , pp. 35-43.

Angelini Luigi (1963). I lavori compiuti per il piano di risanamento di Bergamo alta (1936-1943, 1950-1960). Bergamo: Stamperia Conti.

Aricò Nicola (1999). Illimite Peloro. Messina: Mesogea Editrice.

Calzana Pino, Caccia Bruno (2008). Attorno a Santa Croce. In La rivista di Bergamo, n. 54/2008.

Cardaci Alessio, Versaci Antonella (20I3). Image-based 3D modeling vs laser scanning for the analysis of medieval architecture: the case of St. Croce church in Bergamo. In ISPRS - The international archives of the photogrammetry, remote sensing and spatial information sciences, 40-5/w2.

Cardaci Alessio, Versaci Antonella, Gallina Dario (20 I3). Laser Scanner 3D per la catalogazione dell'Architettura Medioevale: la chiesa di Santa Croce in Bergamo. In Archeologia e calcolatori 24/2013, pp. 209-229.

Fortunati Maria, Vitali Mariagrazia (2000). Bergamo, cappella di Santa Croce. Le strutture ipogee tra età romana e medioevo. In Notiziario della soprintendenza per i beni archeologici della Lombardia, 2010/20I I, pp. 199-202.

Ghiroldi Angelo (2007). La cappella di Santa Croce in Bergamo. In Fortunati Maria, Poggiani Keller Ruggiero (a cura di). Storia economica e sociale di Bergamo. I primi millenni, dalla preistoria al medioevo. Bergamo: Fondazione per la storia economica e sociale di Bergamo. pp. 534-538.

Venanzio Ortensia ( 1959). Costruzioni romaniche a sistema centrale nel bergamasco. In Arte Lombarda IV/I, pp. 29-35.

\section{Authors}

Alessio Cardaci, Università degli Studi di Bergamo, alessio.cardaci@unibg.it

Sereno Innocenti, Università degli Studi di Brescia, sereno.innocenti@unibs.it

To cite this chapter. Cardaci Alessio, Innocenti Sereno (2020). Dal faro per il mare al pozzo per il cielo: la chiesa di Santa Croce a Bergamo nella memoria di Santa Maria della Grotta a Messina/From the lighthouse to the sea to well for the sky: the church of Santa Croce in Bergamo in the memory of Santa Maria Della Grotta. In Arena A., Arena M., Brandolino R.G., Colistra D., Ginex G., Mediati D., Nucifora S., Raffa P. (a cura di). Connettere. Un disegno per annodare e tessere. Atti del $42^{\circ}$ Convegno Internazionale dei Docenti delle Discipline della Rappresentazione/Connecting Drawing for weaving relationships. Proceedings of the 42th International Conference of Representation Disciplines Teachers. Milano: FrancoAngeli, pp. $1902-1923$. 